\title{
WOMEN'S RIGHTS UNVEILED: TALIBAN'S TREATMENT OF WOMEN IN AFGHANISTAN
}

\section{INTRODUCTION}

I have four children. Life is very difficult under the Taliban, especially because of what they have done to women. During the past year, I have been out of my house only three times, always accompanied by a male family member, or my husband.

Once, I went to the baker's [sic]. There I saw another woman. She was picking up some bread, and her sleeves moved up her arms a bit, and a Talib came and beat her. I became very afraid, and I ran away.

My house in Afghanistan is not very big. It has two rooms, one bathroom, and a kitchen. All the day, I am inside the house, doing housework - cooking, washing, cleaning, things like this. My husband is a shopkeeper.

We have a courtyard, so sometimes I can go outside and feel the sun on my face. It is surrounded by a high wall, so no one can see in.

I do not see my women friends. If the women have the time to go outside, the male members of the family don't have time to escort them, or don't want to. So we all stay in our houses.'

It is hard for people in other countries to believe that we women in Afghanistan are beaten everyday by the Taliban. The sadness in our story is endless.

I know that they [the Taliban] beat us, lash us, and lock us in our homes all because they want to destroy the dignity of women. But all these crimes against us will not stop our struggle.

Will other women in the world join with us? ${ }^{2}$

1. Deborah EuUs, WOMEN OFTHE AFGHAN WAR 229 (2000). This story is a testimonial of an Afghan woman, Tahar, describing her life in Afghanistan. See id. For other testimonials of Afghan women and refugees, see id.

2. Id. at 234. This speech was given by an Afghan woman at International Women's Day. See id. 
The Taliban, ${ }^{3}$ the current rulers of Afghanistan, impose rules on women pertaining to their social lives, dress, education, employment, and access to health care services. ${ }^{4}$ Women who do not follow these rules endure degrading treatment and torture. ${ }^{5}$

Women's lives were not always this way. Part II of this Note discusses the history of Afghanistan. Afghanistan has been engaged in war for over thirty years. ${ }^{6}$ During the reign of the Soviet Union in Afghanistan, from 1979 to 1992, women enjoyed equal rights and expanded job opportunities.' These rights became severely impaired, however, after the Communist government fell and the Taliban began to take over the country. ${ }^{8}$ Part III of the Note discusses the recent constitutional history of Afghanistan. The 1990 Constitution, which protected gender equality, ${ }^{9}$ is no longer in force ${ }^{10}$

The Taliban is not the recognized government of Afghanistan. ${ }^{11}$ Part IV of the Note describes the recognized government headed by Burnhanuddin Rabbani, the prior president. Part V of the Note discusses human rights doctrines to which Afghanistan is a party including the International Covenant on Economic, Social and Cultural Rights, the International Covenant on Civil and Political Rights, and the Convention Against Torture and Other Cruel, Inhuman or Degrading Treatment or Punishment. Also examined is Afghanistan's position as a signatory party to the Convention on the Elimination of All Forms of Discrimination Against Women. ${ }^{12}$ As such, the Taliban's actions cannot contradict the objectives of this Convention. ${ }^{13}$ The Taliban and the Rabbani government are both bound by these human rights doctrines. $^{14}$

The situation for women prior to Taliban control is discussed in Part VI. In general, women worked in a broad range of jobs and enjoyed social, economic, and political freedom. ${ }^{15}$ Part VII describes rules the Taliban imposes and how these rules violate the human rights doctrines to which Afghanistan is a party. The Taliban rules affect women's freedom of movement, thought, expression, peaceful assembly, association, religion,

3. Taliban is defined as "student of Islamic religious studies." Id. at 60 . The Taliban also refer to themselves as the Islamic Emirate of Afghanistan. See S. Res. 1267, U.N. SCOR, at 236 (1999), reprinted in 38 I.L.M. 235. The Inter Services Intelligence Division, Pakistan's security service, created the Taliban. See EuUS, supra note 1, at 60. Pakistan and Saudi Arabia fund the Taliban. See id. at 61 . The Taliban were given over $\$ 10$ billion dollars in weapons and aid for their cause. See AHMED RASHID, TALIBAN: MIITANT ISLAM, OILAND FUNDAMENTALISM IN CENTRAL ASIA 18 (2000).

4. See infra notes $187-224,230-334$ and accompanying text.

5. See infra notes 335-343 and accompanying text.

6. See infra notes 20-59 and accompanying text.

7. See infra notes $23,172-82$ and accompanying text.

8. See infra part VII.

9. See infra note 70 and accompanying text.

10. See infra note 83 and accompanying text.

11. See infra notes $86-90$ and accompanying text.

12. See infra note 108 and accompanying text.

13. See infra note 110 and accompanying text.

14. See infra notes $157-171$ and accompanying text.

15. See infra notes $172-182$ and accompanying text. 
employment, education, and political life. ${ }^{16}$ Also infringed are women's rights to health services, to partake in the government, and to be free from torture. ${ }^{17}$ The Taliban's policies amount to a violation of all governing human rights doctrines. ${ }^{18}$

The Taliban justify their strict rules through the tenets of the Islamic religion. ${ }^{19}$ Part VIII analyzes the Taliban's rules in relation to the Islamic culture, and explores the proposition that, in addition to violating governing human rights doctrines, the Taliban are also violating the key premises of the Islamic religion. Part IX discusses possible methods for change including gradualism and influences from organizations, such as the United Nations. Part X describes the lives of Afghan refugees who have fled the country in hopes of a better life. In conclusion, Part XI of the Note suggests that the Taliban must allow input into the governance of the country and repeal all laws that violate human rights doctrines. At a minimum, the Taliban should liberally interpret Islamic law.

\section{HISTORY OF AFGHANISTAN ${ }^{20}$}

The Soviet Union ${ }^{21}$ ruled Afghanistan from 1979 to $1992 .{ }^{22}$ During the Soviet reign in the 1980s, the Communists legally guaranteed women equal rights. ${ }^{23}$ Women saw expanded opportunities in the areas of education and employment. ${ }^{24}$ While some women took advantage of these prospects, other women engaged in warfare against the Communists, ${ }^{25}$ open protests, ${ }^{26}$ and underground activities. ${ }^{27}$ Punishments for these activities included beatings, arrests, torture, and imprisonment. ${ }^{28}$

16. See infra notes 187-229, 258-335 and accompanying text.

17. See infra notes 230-257, 335-353 and accompanying text.

18. See infra notes $187-353$ and accompanying text.

19. See infra note 354 and accompanying text.

20. For a summary of the history of Afghanistan since its inception see Marjon E. Ghasemi, Islam, Intemational Human Rights \& Women's Equality: Afghan Women Under Taliban Rule, 8 S. CAL. REV. L. \& WOMEN'S STUD. 445, 447-49 (1999). See also J. Alexander Their, Afghanistan: Minority Rights and Autonomy in a Multi-Ethnic Failed State, 35 STAN. J. INT'L. L. 351, 361-64 (1999) (discussing the history of the creation of Afghanistan).

21. See generally W. Michael Resiman and James Silk, Which Law Applies to the Afghan Conflict?, 82 AM. J. INT'L. L. 459, 466-79 (1988) for the Soviet Union's historical role in Afghanistan.

22. See Euss, supra note 1, at xviii.

23. See id. at xviii, 40 .

24. See id. at 40. id. at 8.

25. In Herat, women guerrillas fought in the countryside against the Communists. See

26. In the children's revolt on April 21, 1980, high school girls in Kabul protested. See id. at xviii. The demonstration ended many days later with thousands of arrests. See id. at 8. Fifty students, including thirty females, were killed. See id. at xviii. In 1983, in the capital of Kabul, mourning women sought the dead bodies of their loved ones, and the discharge of jailed Afghans. See id. at 7-8.

27. The underground group was divided into three sections. See id. at 8 . The first group investigated suspected spies. The second group trailed the suspects to determine their connections. The third group assassinated Russians. See id.

28 . Women reportedly were beaten, burned with cigarettes, forced to stand outside in the 
The Soviet troops left Afghanistan in 1989. ${ }^{29}$ The Mujahideen ${ }^{30}$ fought against the Communists until the reign officially ended in $1992 .{ }^{31}$ The United States, ${ }^{32}$ Egypt, Pakistan, and China supported the Mujahideen with weapons and funding. ${ }^{33}$

The government changed in $1992,{ }^{34}$ and Burnhanuddin Rabbani acted as the interim president. ${ }^{35}$ The Afghan Peace Accord created the government structure. ${ }^{36}$ The government offices included a president, prime minister, and a cabinet. ${ }^{37}$ Unfortunately, the government structure did not provide needed stability in the country. ${ }^{38}$ A rivalry between groups supporting the president and those supporting the prime minister ensued and fighting continued. ${ }^{39}$

\section{A. Taliban Begin to Take Control}

The Taliban $^{40}$ began to emerge victorious in November, $1994 .^{41}$ The Taliban, a group comprised of men, received their education in religious schools known as madrassas. ${ }^{42}$ The Taliban learned that "women were a temptation, an unnecessary distraction ...."43 As members of the Pashtun clan, ${ }^{44}$ the Taliban follow strict rules pertaining to social relationships. ${ }^{45}$

hot sun for a long period of time, shocked with electricity, and forced to withstand objects inserted into their rectum. See id. at 9.

29. See AFG. CONST., reprinted in Felix Ermacora, Afghanistan, in CONSTITUTIONSOFTHE COUNTRIES OF THE WORLD 3 (Albert P. Blaustein \& Gisbert H. Flanz eds., 1992).

30. Mujahideen means "[h]oly warriors fighting jihad or holy war." RASHID, supra note 3, at 243. For a glossary of Afghan terms, see id. at 243-44.

31. See ELLS, supra note 1 , at xviii, 42.

32. The United States spent six million dollars in aid to the guerilla groups. See id. at 43. Funds continued after the Soviets left. See id. The United States spent over three million dollars to support Gulbuddin Hekmatyr, the leader of the Hezb-e Islami party. See id. Hekmatyr fought against the Communists and then against the other groups to get control. See id.

33. See id. at 41,43 . The Soviet Union spent $\$ 45$ billion fighting the Mujahideen. See RASHID, supra note 3 , at 18.

34. See EuIs, supra note 1, at xviii, 42.

35. See Final Report on the Situation of Human Rights in Afghanistan, U.N. ESCOR, 49th Sess., Agenda Item 12, 143, U.N. Doc. E/CN.4/1993/42 (1993) [hereinafter Final Report on the Situation of Human Rights in Afghanistan (1993)].

36. See Final Report on the Situation of Human Rights in Afghanistan, U.N. ESCOR, 50th Sess., Agenda Item 12, 11 10, 1 1, 13, U.N. Doc. E/CN.4/1994/53 (1994) [hereinafter Final Report on the Situation of Human Rights in Afghanistan (1994)].

37. See id. 113.

38. See id.

39. See id.

40. For general information on the Taliban, see supra note 3 .

41. See Final Report on the Situation of Human Rights in Afghanistan, U.N. ESCOR, 51 st Sess., Agenda Item 12, 1 17, U.N. Doc. E/CN.4/1995/64 (1995) [hereinafter Final Report on the Situation of Human Rights in Afghanistan (1995)] .

42. See RASHID, supra note 3, at 22-23. See also EuLIs, supra note 1, at 60 .

43. RASHID, supra note 3, at 33. "They were raised by men, men with a disregard for women that is cultural, religious, and, primarily, political." EuLs, supra note 1 , at 60 .

44. For information about the Pashtun clan see RASHD, supra note 3, at 10-12. See also Ghasemi, supra note 20 , at 448.

45. See Ghasemi, supra note 20, at 448 . The tradition of the Pashtuns is to disregard Islamic inheritance laws. See Anastasia Telesetsky, In the Shadows and Behind the Veil: Women in Afghanistan Under Taliban Rule, 13 BERKELEY WOMEN's L.J. 293-95 (1998). 
The Taliban formed with good intentions. Their goals were to "restore peace, disarm the population, enforce Sharia law and defend the integrity and Islamic character of Afghanistan."46 The Taliban attempted to end internal fighting. ${ }^{47}$ After they conquered the city of Kandahar in 1994, an estimated twenty thousand Afghans joined in support along with hundreds of madrassa students from Pakistan. ${ }^{48}$

In 1995, three groups, one of which was the Taliban, vied for control of Afghanistan. ${ }^{49}$ Later that year, the Rabbani government offered to transfer power to a new government, one which all parties could agree upon..$^{50}$ However, the parties did not stop fighting long enough to reach an agreement. ${ }^{51}$ The Taliban emerged victorious in Herat in $1995,{ }^{52}$ the capital, Kabul, in 1996, ${ }^{53}$ and Bamiyan in 1998. ${ }^{54}$

In 1999, two factions, the Taliban and the United Front, fought for control. ${ }^{55}$ These groups attempted to compromise in $1999 .{ }^{56}$ The negotiations ended when the Taliban decided the United Front must agree to join their

Women are not given property rights and are forced into marriage. See id.

46. RASHID, supra note 3, at 22. The leader of the Taliban, Mullah Mohammed Omar, stated the intentions of the Taliban when he said, “We took up arms to achieve the aims of the Afghan jihad and save our people from further suffering at the hands of the so-called Mujaheddin. We had complete faith in God Almighty. We never forgot that. He can bless us with victory or plunge us into defeat." Id. at 23 . Omar is a very secretive leader. See id. He resides in the city of Kandahar and has been to Kabul, the capital, only twice. See id. Omar remains cut-off from the Western world by refusing to speak to journalists or diplomats. See id. For the history of Omar's life see id. at 23-26. See Ghasemi, supra note 20, at 453. The law that encompasses Islamic jurisprudence is the Shari'a. See id.

47. See id. at 22.

48. See id. at 31. Many boys that engaged in fighting were between fourteen and twentyfour years old. See id. at 32.

49. The three groups were "the Taliban, the forces controlled by General Dostum together with his supporters in the Supreme Coordination Council and the government forces of President Rabbani." Final Report on the Situation of Human Rights in Afghanistan, U.N. ESCOR, 52nd Sess., Agenda Item 10, I 14, U.N. Doc. E/CN.4/1996/64 (1996) [hereinafter Final Report on the Situation of Human Rights in Afghanistan (1996)].

50. See id. 118.

51. See id.

52. See EuIS, supra note 1, at xix.

53. See id. The Taliban executed a former President of Afghanistan, Mohammed Najibullah. See Interim Report on the Situation of Human Rights in Afghanistan, U.N. GAOR, 51 st Sess., Agenda Item 1 10(c), 957, U.N. Doc. A/51/481 (1996) [hereinafter Interim Report on the Situation of Human Rights in Afghanistan (1996)]. It was estimated that the Taliban controlled three quarters of Afghanistan in 1996. See id. See also Final Report on the Situation of Human Rights in Afghanistan, U.N. ESCOR, 53rd Sess., Agenda Item 10, 118, U.N. Doc. E/CN.4/1997/59 (1997) [hereinafter Final Report on the Situation of Human Rights in Afghanistan (1997)]. The remaining areas of Afghanistan are controlled mostly by Supreme Council for the Defence of Afghanistan. See id. T14, 18.

54. See Eurs, supra note 1, at xix.

55. See Report on the Situation of Human Rights, U.N. ESCOR, 55th Sess., Agenda Item 9, I 11, U.N. Doc. E/CN.4/1999/40 (1999) [hereinafter Report on the Situation of Human Rights (1999)].

56. Both groups accepted a peace accord that consisted of a proposal for a power-sharing government and a cease-fire. See id. 11 14. See also The Situation in Afghanistan and Its Implications For International Peace and Security, U.N. GAOR, 54th Sess., Agenda Item 50, I10-14, U.N. Doc. A/54/536, S/1999/1145 (1999) [hereinafter The Situation in Afghanistan and Its Implications for International Peace and Security]. 
system of government. ${ }^{57}$ The Taliban currently control ninety-seven percent of Afghanistan ${ }^{58}$ and seek formal recognition. ${ }^{59}$

\section{B. Taliban's Governing Structure and Style}

The Taliban government is "neither parliamentary nor presidential, but Islamic." The Taliban strictly enforce Islamic law. ${ }^{61}$ The "Department for enforcement of right Islamic way and prevention of evils," or the religious police, punish violations of Taliban decrees and Islamic rules. ${ }^{62}$ Each province that the Taliban rules has Taliban officials presiding over it. ${ }^{63}$ However, Taliban policies are not carried out similarly in all areas because of an inefficient administrative structure ${ }^{64}$ Religious courts and tribunals, which also apply Islamic law, exist in all provinces. ${ }^{65}$

\section{CONSTITUTIONAL HistoRy OF AFGHANISTAN}

The Soviet departure from Afghanistan in $1989^{66}$ set the stage for a new Constitution. $^{67}$ The 1990 Constitution of the Republic of Afghanistan ${ }^{68}$ implemented Islam as the state religion, ${ }^{69}$ gave men and women equal rights, ${ }^{70}$

57. See The Situation in Afghanistan and Its Implications For Intermational Peace and Security, supra note $56,712$.

58. See Interim Report on the Situation of Human Rights in Afghanistan, U.N. GAOR, 54th Sess., Agenda Item 116 (c), 136, U.N. Doc. A 54/422 (1999) [hereinafter Interim Report on the Situation of Human Rights in Afghanistan (1999)].

59. 59 See Interim Report on the Situation of Human Rights in Afghanistan (1996), supra note 53, 58. The Taliban stated that they could satisfy the United Nations' three main concerns if they were recognized. See Interim Report on the Situation of Human Rights in Afghanistan (1999), supra note 58, 736,38 . The Taliban viewed the United Nations' three concerns before recognition would be given to them as "(a) elimination of narcotic drugs; (b) dealing with Osama bin Laden [suspected terrorist]; (c) education of women and girls." Id. I 38. The Special Rapporteur noted, however, that recognition of the Taliban was not related to the these concems. See id. 140. ฯ13.

60. Final Report on the Situation of Human Rights in Afghanistan (1997), supra note 53,

61. See id. 13.

62. See id.

63. See id. 928.

64. See id.

65. See id. 129.

66. See AFG. CONST, reprinted in Felix Ermacora, Afghanistan, in CONSTTUTIONS OFTHE COUNTRIES OF THE WORLD 3 (Albert P. Blaustein \& Gisbert H. Flanz eds., 1992).

67. See id. at 4,5 .

68. The Constitution of the Republic of Afghanistan replaced the 1987 constitution. See Their, supra note 20 , at 368 . The preamble to the Constitution provided:

Therefore, keeping in mind the historic changes that have taken shape in our homeland and in the contemporary world, adhering to the principles of the sacred religion of Islam, abiding by the accepted Afghan traditions and rituals, relying upon the realities of the country's history and culture, respecting the valuable heritages of the Constitutionalist Movement and in conformity with the Charter of the United Nations and the Universal Declaration of Human Rights . . . .

AFG. CONST., reprinted in Felix Ermacora, Afghanistan, in CONSTITUTIONS OFTHE COUNTRIES OF THE WORLD 9 (Albert P. Blaustein \& Gisbert H. Flanz eds., 1992). For the history of the Constitution see Their, supra note 20, at 366-70.

69. Chapter 1, Article 2 provides, "The sacred religion of Islam is the religion of 
denounced torture, ${ }^{71}$ allowed freedom of expression, ${ }^{72}$ acknowledged freedom of assembly, ${ }^{73}$ allowed government criticism, ${ }^{74}$ recognized the right to work, ${ }^{75}$ the right to an education, ${ }^{76}$ and the right to health services. ${ }^{77}$ The Constitution set the Loya Jirgah ${ }^{78}$ as the governing body. ${ }^{79}$ The government consisted of a president, a 205 seat parliament, and a supreme court. ${ }^{80}$

Chapter 12 of the Constitution discusses foreign policy and mentions the observance of the United Nations Charter and the Universal Declaration of Human Rights. ${ }^{81}$ Furthermore, the Constitution provides that all Afghan

Afghanistan. In the Republic of Afghanistan no law shall run counter to the principles of the sacred religion Islam and other values enshrined in this Constitution." AFG. CONST., reprinted in Felix Ermacora, Afghanistan, in CONSTITUTIONS OF THE COUNTRIES OF THE WORLD 10-11 (Albert P. Blaustein \& Gisbert H. Flanz eds., 1992).

70. Chapter 3, Article 38 states, "Citizens of the Republic of Afghanistan, both men and women, have equal rights and duties in the eyes of the law ...." Id. at 18.

71. Chapter 3 Article 42 states, "In the Republic of Afghanistan, punishment incompatible with human dignity, torture and excruciation are prohibited." $1 d$. at 19.

72. Chapter 3, Article 49 provides, "Citizens of the Republic of Afghanistan enjoy the right of freedom of thought and expression." Id. at 21.

73. Chapter 3, Article 50 states, "Citizens of the Republic of Afghanistan enjoy the right to assembly, peaceful demonstration and strike, in accordance with the provisions of the law." Id.

74. Chapter 3, Article 51 provides:

Citizens of the Republic of Afghanistan enjoy the right to petition, criticise and make suggestions, either individually or collectively.

State organs, social organisations and responsible officials are bound to consider the petitions, criticisms and proposals and take necessary actions in regard to

Id.

them within the time prescribed by law. Surveillance for criticism is forbidden.

75. Chapter 3, Article 52 states, "Citizens of the Republic of Afghanistan have the right to work and are entitled to equal pay for equal work. The state, through enactment and application of just and progressive labour laws, shall provide necessary conditions for the citizens to enjoy this right." Id. at 21-22.

76. Chapter 3, Article 56 states:

Citizens of the Republic of Afghanistan have the right to free education.

The State shall adopt necessary measures for the eradication of illiteracy, generalization of balanced education, education in mother tongue, ensuring compulsory primary education, gradual expansion of general, technical, professional and vocational education and growth of the system of higher education for training national cadres.

Id. at 22-23.

77. Chapter 3, Article 57 states:

Citizens of the Republic of Afghanistan have the right to health and social security. The state shall adopt necessary measures for expansion of all-round, balanced and countrywide medical services, expansion of hospitals, health centres, training of doctors and personnel for medical services, universal prevention of diseases, expansion of free health services, arrangement and encouragement of private medical services, improvement of material welfare Id. at 23. of the age, war and work disabled and dependents of martyrs.

78. See id. at 25. The Loya Jirgah consists of the elected President and other governing officers. See id. at Chapter 4.

79. See id.

80. See Shefali Desai, Hearing Afghan Women's Voices: Feminist Theory's Reconceptualization of Women's Human Rights, 16 ARIZ. J. INT'L \& COMP. L. 805, 819 (1999).

81. Chapter 12, Article 133 states, "The Republic of Afghanistan respects and observes the UN Charter, the Universal Declaration of Human Rights and other accepted principles and norms of international law." See AFG. CONST., reprinted in Felix Ermacora, Afghanistan, in 
citizens are bound by the Constitution. ${ }^{82}$

After the Communist government fell, the Constitution was discarded..$^{83}$ The Taliban have imposed new rules ${ }^{84}$ and claim to be creating a new constitution. ${ }^{85}$

\section{WHO REPRESENTS THE RECOGNIZED GOVERNMENT OF AFGHANISTAN?}

The Taliban and the prior government each claim to be the only legitimate government. ${ }^{86}$ Former President Burnhanuddin Rabbani controls most of Afghanistan's embassies ${ }^{87}$ and holds the United Nations seat for Afghanistan. ${ }^{88}$ The Taliban cannot occupy Afghanistan's seat because the group is not recognized internationally. ${ }^{89}$ The only countries that currently recognize the Taliban as the government of Afghanistan are Pakistan, Saudi Arabia, and the United Arab Emirates. ${ }^{90}$

\section{GOVERNING HUMAN RIGHTS DOCTRINES}

\section{A. Universal Declaration of Human Rights}

All countries must abide by the principles of the Universal Declaration of Human Rights' (UDHR). The UDHR provides for equality between men

CONSTITUTIONS OF THE COUNTRIES OF THE WORLD 46 (Albert P. Blaustein \& Gisbert H. Flanz eds., 1992).

82. Chapter 3, Article 61 states, "Every citizen of the Republic of Afghanistan is bound to observe the Constitution and the laws of the Republic of Afghanistan. Ignorance of provisions of law is no excuse." Id. at 24.

83. See EuJs, supra note 1, at xviii, 42.

84. See id. at 62-64.

85. See infra note 349.

86. See STEFAN TALMON, RECOGNTION OFGOVERNMENTS IN INTERNATIONAL LAW: WITH PaRTICULAR REFERENCE TO GOVERNMENTS INEXIIE 8, n.23 (Ian Brownlie ed., 1998). See also Afghanistan Human Rights Practices, 1999, available at http://www.state.gov/www/global/human_rights/1999_hrp_report/afghanis.html (last visited Sept. 2, 2000) [hereinafter Afghanistan Human Rights Practices, 1999].

87. See Afghanistan Human Rights Practices, 1999, supra note 86.

88. See id. See also Amnesty International Annual Report 2000, available at http://www.web.amnesty.org (last visited Sept. 2, 2000). See also Ghasemi, supra note 20, at 464.

89. See Ghasemi, supra note 20 , at 464.

90. See Interim Report on the Situation of Human Rights in Afghanistan, U.N. GAOR, 52nd Sess., Agenda Item 112 (c), 1 20, U.N. Doc. A/52/493 (1997) [hereinafter Interim Report on the Situation of Human Rights in Afghanistan (1997)].

91. See Ghasemi, supra note 20, at 461 . The UDHR Preamble states:

Whereas the peoples of the United Nations have in the Charter reaffirmed their faith in fundamental human rights, in the dignity and worth of the human person and in the equal rights of men and women and have determined to promote social progress and better standards of life in larger freedom.

Universal Declaration of Human Rights, Dec. 10, 1948, Department of State Bulletin, available at LEXIS [hereinafter UDHR]. See also Universal Declaration of Human Rights, reprinted in TWENTY-FIVE HUMAN RIGHTS DOCUMENTS 6 (1994). Article 30 states, "Nothing in this Declaration may be interpreted as implying for any State, group or person any right to engage in any activity or to perform any act aimed at the destruction of any of the rights and freedoms set forth herein." For a discussion of the Taliban's violations of the UDHR, see Ghasemi, supra 
and women, ${ }^{92}$ rights against torture, ${ }^{93}$ protection in one's private life, ${ }^{94}$ right to consent to marriage, ${ }^{95}$ right to own property, ${ }^{96}$ freedom of thought and religion, ${ }^{97}$ right to engage in political affairs, ${ }^{98}$ right to employment, ${ }^{99}$ right to adequate standard of living, ${ }^{100}$ right to education, ${ }^{101}$ and right to engage in the

note 20 , at 461-62. Id.

92. Article 2 states, in part, "Everyone is entitled to all the rights and freedoms set forth in this Declaration, without distinction of any kind, such as race, colour, sex, language, religion, political or other opinion, national or social origin, property, birth or other status." UDHR, supra note 91 .

93. Article 5 states, "No one shall be subjected to torture or to cruel, inhuman or degrading treatment or punishment." Id.

94. Article 12 states, "No one shall be subjected to arbitrary interference with his privacy, family, home or correspondence, nor to attacks upon his honour and reputation. Everyone has the right to the protection of the law against such interference or attacks." Id. Article 13 states in part, "1. Everyone has the right to freedom of movement and residence within the borders of each State." Id.

95. Article 16 states:

1. Men and women of full age, without any limitation due to race, nationality or religion, have the right to marry and to found a family. They are entitled to equal rights as to marriage, during marriage and at its dissolution.

2. Marriage shall be entered into only with the free and full consent of the intending spouses.

3. The family is the natural and fundamental group unit of society and is entitled to protection by society and the State.

Id.

96. Article 17 states, "1. Everyone has the right to own property alone as well as in association with others. 2. No one shall be arbitrarily deprived of his property." ld.

97. Article 18 states, "Everyone has the right to freedom of thought, conscience and religion; this right includes freedom to change his religion or belief, and freedom, either alone or in community with others and in public or private, to manifest his religion or belief in teaching, practice, worship and observance." Id. Article 19 states, "Everyone has the right to freedom of opinion and expression; this right includes freedom to hold opinions without interference and to seek, receive and impart information and ideas through any media and regardless of frontiers." Id.

98. Article 20 states, "1. Everyone has the right to freedom of peaceful assembly and association. 2. No one may be compelled to belong to an association." Id. Article 21 states:

1. Everyone has the right to take part in the government of his country, directly or through freely chosen representatives.

2. Everyone has the right to equal access to public service of his country.

3. The will of the people shall be the basis of the authority of government; this will shall be expressed in periodic and genuine elections which shall be by universal and equal suffrage and shall be held by secret vote or by equivalent free voting procedures.

Id.

99. Article 23 states in part:

1. Everyone has the right to work, to free choice of employment, to just and favourable conditions of work and to protection against unemployment.

2. Everyone, without any discrimination, has the right to equal pay for equal work.

3. Everyone who works has the right to just and favourable remuneration ensuring for himself and his family an existence worthy of human dignity, and supplemented, if necessary, by other means of social protection.

Id.

100. Article 25 states:

1. Everyone has the right to a standard of living adequate for the health and well-being of himself and of his family, including food, clothing, housing and medical care and necessary social services, and the right to security in the event of unemployment, sickness, disability, widowhood, old age or other lack of livelihood in circumstances beyond his control.

2. Motherhood and childhood are entitled to special care and assistance. All 
social life of the culture, ${ }^{102}$ among many other protections. ${ }^{103}$ The prior Afghan Constitution stated that it was in conformity with the UDHR. ${ }^{104}$

\section{B. Convention on the Elimination of All Forms of Discrimination Against Women}

The Convention on the Elimination of All Forms of Discrimination Against Women ${ }^{105}$ (CEDAW) went into effect on September 3, 1981. ${ }^{106}$ There are 167 States Parties ${ }^{107}$ to the CEDAW and three signatories, Afghanistan, ${ }^{108}$

\section{Id. 101. Article 26 provides:}

children, whether born in or out of wedlock, shall enjoy the same social protection.

1. Everyone has the right to education. Education shall be free, at least in the elementary and fundamental stages. Elementary education shall be compulsory. Technical and professional education shall be made generally available and higher education shall be equally accessible to all on the basis of merit.

2. Education shall be directed to the full development of the human personality and to the strengthening of respect for human rights and fundamental freedoms. It shall promote understanding, tolerance and friendship among all nations, racial or religious groups, and shall further the activities of the United Nations for the maintenance of peace.

3. Parents have a prior right to choose the kind of education that shall be given

Id. to their children.

102. Aricle 27 states:

1. Everyone has the right freely to participate in the cultural life of the community, to enjoy the arts and to share in scientific advancement and its benefits.

2. Everyone has the right to the protection of the moral and material interests resulting from any scientific, literary or artistic production of which he is the author.

Id. Article 28 states, "Everyone is entitled to a social and intemational order in which the rights and freedoms set forth in this Declaration can be fully realized." Id.

103. See generally id.

104. See AFG. CONST., reprinted in Felix Ermacora, Afghanistan, in CONSTITUTIONSOFTHE COUNTRIES OF THE WORLD 9 (Albert P. Blaustein \& Gisbert H. Flanz eds., 1992).

105. The Preamble states:

Recalling that discrimination against women violates the principles of equality of rights and respect for human dignity, is an obstacle to the participation of women, on equal terms with men, in the political, social, economic and cultural life of their countries, hampers the growth of the prosperity of society and the family and makes more difficult the full development of the potentialities of women in the service of their countries and of humanity,

The Convention on the Elimination of All Forms of Discrimination Against Women, Jan. 22, 1980, 19 I.L.M. 33, 35 [hereinafter CEDAW]. See also The Convention on the Elimination of All Forms of Discrimination Against Women, reprinted in TWENTY-FIVE HUMAN RIGHTS DOCUMENTS 48 (1994). For a feminist analysis of the CEDAW see Jo Lynn Southard, Protection of Women's Human Rights Under the Convention on the Elimination of All Forms of Discrimination Against Women, 8 PACE INT'L L. REV. 1, 24-85 (1996).

106. See The Convention on the Elimination of All Forms of Discrimination Against Women, reprinted in TWENTY-FIVE HUMAN RIGHTS DOCUMENTS 48 (1994).

107. The parties to the CEDAW are: Albania, Algeria, Andorra, Angola, Antigua and Barbuda, Argentina, Armenia, Australia, Austria, Azerbaijan, Bahamas, Bangladesh, Barbados, Belarus, Belgium, Belize, Benin, Bhutan, Bolivia, Bosnia and Herzegovina, Botswana, Brazil, Bulgaria, Burkina Faso, Burundi, Cambodia, Cameroon, Canada, Cape Verde, Central African Republic, Chad, Chile, China, Colombia, Comoros, Congo, Costa Rica, Cote d'Ivoire, Croatia, 


\section{Sao Tome and Principe, and the United States. ${ }^{109}$ \\ As a signatory to the CEDAW,}

A state is obliged to refrain from acts which would defeat the object and purpose of a treaty when: (a) It has signed the treaty or has exchanged instruments constituting the treaty subject to ratification, acceptance or approval, until it shall have made its intention clear not to become a party to the treaty.... ${ }^{110}$

States Parties to the CEDAW pledge to abolish discriminatory laws, take all appropriate steps to promote essential human rights freedom for women, and abstain from engaging in discriminatory acts along with other activities. ${ }^{11}$

Cuba, Cyprus, Czech Republic, Democratic People's Republic of Korea, Democratic Republic of the Congo, Denmark, Djibouti, Dominica, Dominican Republic, Ecuador, Egypt, El Salvador, Equatorial Guinea, Eritrea, Estonia, Ethiopia, Fiji, Finland, France, Gabon, Gambia, Georgia, Germany, Ghana, Greece, Grenada, Guatemala, Guinea, Guinea-Bissau, Guyana, Haiti, Honduras, Hungary, Iceland, India, Indonesia, Iraq, Ireland, Israel, Italy, Jamaica, Japan, Jordan, Kazakhstan, Kuwait, Kyrgyzstan, Lao People's Democratic Republic, Latvia, Lebanon, Lesotho, Liberia, Libyan Arab Jamahiriya, Liechtenstein, Lithuania, Luxembourg, Madagascar, Malawi, Malaysia, Maldives, Mali, Malta, Mauritius, Mexico, Mongolia, Morocco, Mozambique, Myanmar, Namibia, Nepal, Netherlands, New Zealand, Nicaragua, Niger, Nigeria, Norway, Pakistan, Panama, Papua New Guinea, Paraguay, Peru, Philippines, Poland, Portugal, Republic of Korea, Republic of Moldova, Romania, Russian Federation, Rwanda, Saint Kitts and Nevis, Saint Lucia, Saint Vincent and the Grenadines, Samoa, Saudi Arabia, Senegal, Seychelles, Sierra Leone, Singapore, Slovakia, Slovenia, South Africa, Spain, Sri Lanka, Suriname, Sweden, Switzerland, Tajikistan, Thailand, The Former Yugoslav Republic of Macedonia, Togo, Trinidad and Tobago, Tunisia, Turkey, Turkmenistan, Tuvalu, Uganda, Ukraine, United Kingdom of Great Britain and Northern Ireland, United Republic of Tanzania, Uruguay, Uzbekistan, Vanuatu, Venezuela, Viet Nam, Yemen, Yugoslavia, Zambia, and Zimbabwe. See Office of the United Nations High Commissioner for Human Rights, Status of Ratifications of the Principal International Human Rights Treaties, at http://www.unhchr.ch/pdf/report.pdf (last modified Mar. 19, 2001) [hereinafter Status of Ratifications of the Principal International Human Rights Treaties].

108. Afghanistan signed the CEDAW on August 14, 1980. See id.

109. The United States signed the CEDAW on July 17, 1980. See id. Secretary of State Madeline Albright said at a women's conference, "[A]fter 18 years, it is long past time for America to become [a] party to the Convention on the Elimination of All Forms of Discrimination Against Women." Secretary of State Madeline Albright, Women and Foreign Policy: A Call to Action, Remarks at the Women's Conference, Los Angeles, California, Oct. 5, 1999, available at LEXIS, Department of State Dispatch File. On the situation in Afghanistan, Secretary Albright said, "[T]he Taliban, seems determined to drag Afghan women back from the dawn of the 21 st century to somewhere closer to the 13 th. The only female rights they appear to recognize are the rights to remain silent and uneducated, unheard, and unemployed." Id. Even though the United States has refused to ratify the CEDAW for twenty years, the city of San Francisco passed a city ordinance to ratify the CEDAW in 1998. Editorial, The Shame of the Senate, SAN FRANCISCO CHRONICLE, July 14, 2000, available at LEXIS, News Group file.

110. Vienna Convention on the Law of Treaties, Jan. 27, 1988, art. 18, 1155 U.N.T.S. 331 reprinted in BURNS, WESTON \& CHARLESWORTH, SUPPLEMENT OF BASIC DOCUMENTS TO INTERNATIONAL LAW AND WORLD ORDER 69, 73 (1997).

111. Part I, Article 2 states:

States Parties condemn discrimination against women in all its forms, agree to pursue by all appropriate means and without delay a policy of eliminating discrimination against women and, to this end, undertake:

(a) To embody the principle of the equality of men and women in their 
The CEDAW defines discrimination as:

[A]ny distinction, exclusion or restriction made on the basis of sex which has the effect or purpose of impairing or nullifying the recognition, enjoyment or exercise by women, irrespective of their marital status, on a basis of equality of men and women, of human rights and fundamental freedoms in the political, economic, social, cultural, civil or any other field. ${ }^{12}$

The CEDAW's purpose is to promote and insure equality of men and women in all aspects of life including employment, ${ }^{113}$ health, ${ }^{114}$ education, ${ }^{115}$

national constitutions or other appropriate legislation if not yet incorporated therein and to ensure, through law and other appropriate means, the practical realization of this principle;

(b) To adopt appropriate legislative and other measures, including sanctions where appropriate, prohibiting all discrimination against women;

(c) To establish legal protection of the rights of women on an equal basis with men and to ensure through competent national tribunals and other public institutions the effective protection of women against any act of discrimination;

(d) To refrain from engaging in any act or practice of discrimination against women and to ensure that public authorities and institutions shall act in conformity with this obligation;

(e) To take all appropriate measures to eliminate discrimination against women by any person, organization or enterprise;

(f) To take all appropriate measures, including legislation, to modify or abolish existing laws, regulations, customs and practices which constitute discrimination against women;

(g) To repeal all national penal provisions which constitute discrimination against women.

CEDAW, supra note 106, at 36. Part 1, Article 3 states:

State Parties shall take in all fields, in particular in the political, social, economic and cultural fields, all appropriate measures, including legislation, to ensure the full development and advancement of women, for the purpose of guaranteeing them the exercise and enjoyment of human rights and fundamental freedoms on a basis of equality with men.

Id. See Division for the Advancement of Women, available at http://www.un.org/ womenwatch/daw/cedaw/index.html (last visited Mar. 27, 2001).

112. Part I, Article 1 of the CEDAW, supra note 106, at 36.

113. Part III, Article 11 states:

1. States Parties shall take all appropriate measures to eliminate discrimination against women in the field of employment in order to ensure, on a basis of equality of men and women, the same rights, in particular:

(a) The right to work as an inalienable right of all human beings;

(b) The right to the same employment opportunities, including the application of the same criteria for selection in matters of employment;

(c) The right to free choice of profession and employment, the right to promotion, job security and all benefits and conditions of service and the right to receive vocational training and retraining, including apprenticeships, advanced vocational training and recurrent training;

(d) The right to equal remuneration, including benefits, and to equal treatment in respect of work of equal value, as well as equality of treatment in the evaluation of the quality of work;

(e) The right to social security, particularly in cases of retirement, unemployment, sickness, invalidity and old age and other incapacity 
cultural life, ${ }^{116}$ political affairs, ${ }^{117}$ legal matters, ${ }^{118}$ and home life. ${ }^{119}$ The

Id. at 39.

to work, as well as the right to paid leave:

(f) The right to protection of health and to safety in working conditions, including the safeguarding of the function of reproduction.

114. Part III Article 12 states:

1. States Parties shall take all appropriate measures to eliminate discrimination against women in the field of health care in order to ensure, on a basis of equality of men and women, access to health care services, including those related to family planning.

2. Notwithstanding the provisions of paragraph 1 of this article, States Parties shall ensure to women appropriate services in connection with pregnancy, confinement and the post-natal period, granting free services where

Id. at 40. necessary, as well as adequate nutrition during pregnancy and lactation.

115. Part III, Article 10 states:

States Parties shall take all appropriate measures to eliminate discrimination against women in order to ensure to them equal rights with men in the field of education and in particular to ensure, on a basis of equality of men and women:

(a) The same conditions for career and vocational guidance, for access to studies and for the achievement of diplomas in educational establishments of all categories in rural as well as in urban areas; this equality shall be ensured in preschool, general, technical, professional and higher technical education, as well as in all types of vocational training;

(b) Access to the same curricula, the same examinations, teaching staff with qualifications of the same standard and school premises and equipment of the same quality;

(c) The elimination of any stereotyped concept of the roles of men and women at all levels and in all forms of education by encouraging coeducation and other types of education which will help to achieve this aim and, in particular, by the revision of textbooks and school programmes and the adaptation of teaching methods;

(d) The same opportunities to benefit from scholarships and other study grants;

(e) The same opportunities for access to programmes of continuing education, including adult and functional literacy programmes, particularly those aimed at reducing, at the earliest possible time, any gap in education existing between men and women.

(f) The reduction of female student drop-out rates and the organization of programmes for girls and women who have left school prematurely;

(g) The same opportunities to participate actively in sports and physical education;

(h) Access to specific educational information to help to ensure the health and well-being of families, including information and advice on family

Id. at 38-39. planning.

116. Part I, Article 5 states in part:

States Parties shall take all appropriate measures:

(a) To modify the social and cultural patterns of conduct of men and women, with a view to achieving the elimination of prejudices and customary and all other practices which are based on the idea of the inferiority or the superiority of either of the sexes or on stereotyped

Id. at 37. roles for men and women;

117. Part II, Article 7 states:

States Parties shall take all appropriate measures to eliminate discrimination against women in the political and public life of the country and, in particular, shall ensure to women, on equal terms with men, the right:

(a) To vote in all elections and public referenda and to be eligible for election to all publicly elected bodies;

(b) To participate in the formulation of government policy and the 
CEDAW has a special provision for the protection of women living in rural areas. ${ }^{120}$ The CEDAW is the sole human rights treaty to confirm women's reproductive rights. ${ }^{121}$

The Committee on the Elimination of Discrimination Against Women (Committee) oversees the State reporting measures and prepares comments, suggestions, and general recommendations for the States Parties. ${ }^{122}$

The Optional Protocol to the Convention on the Elimination of All Forms of Discrimination Against Women (Protocol) provides a reporting

implementation thereof and to hold public office and perform all public functions at all levels of government;

(c) To participate in non-governmental organizations and associations concerned with the public and political life of the country.

Id.

118. Part IV, Article 15 states in part, "1. States Parties shall accord to women equality with men before the law." Id. at 41.

119. Part IV, Article 16 states in part:

1. States Parties shall take all appropriate measures to eliminate discrimination against women in all matters relating to marriage and family relations and in particular shall ensure, on a basis of equality of men and women:

(a) The same right to enter into marriage;

(b) The same right freely to choose a spouse and to enter into marriage only with their free and full consent;

(c) The same rights and responsibilities during marriage and at its dissolution; ... .

(h) The same rights for both spouses in respect of the ownership, acquisition, management, administration, enjoyment and disposition

Id. at 41-42. of property, whether free of charge or for a valuable consideration.

120. Part III, Article 14 states in part:

1. States Parties shall take into account the particular problems faced by rural women and the significant roles which rural women play in the economic survival of their families, including their work in the non-monetized sectors of the economy, and shall take all appropriate measures to ensure the application of the provisions of this Convention to women in rural areas.

2. States Parties shall take all appropriate measures to eliminate discrimination against women in rural areas in order to ensure, on a basis of equality of men and women, that they participate in and benefit from rural development and, in particular, shall ensure to such women the right: ...

(b) To have access to adequate health care facilities, including information, counselling and services in family planning; ...

(d) To obtain all types of training and education, formal and non-formal, including that relating to functional literacy, as well as, inter alia, the benefit of all community and extension services, in order to increase their technical proficiency; ... .

(f) To participate in all community activities;...

(h) To enjoy adequate living conditions, particularly in relation to housing, sanitation, electricity and water supply, transport and communications.

Id. at 40-41.

121. See Division for the Advancement of Women, available at http://www.un.org/womenwatch/daw/cedaw/index.html (last visited Mar. 27, 2001) (discussing the CEDAW). See CEDAW, supra note 106, part I, article 5, part III, article 12, part III, article 14, part IV, article 16.

122. For a summary of the role of the Committee, see The Committee on the Elimination of Discrimination Against Women, available at http://www.un.org/womenwatch/ daw/cedaw/committ.htm (last visited Mar. 27, 2001). For the exact procedures for States Parties to the CEDAW, see the CEDAW, supra note 105, part V. See also Southard, supra note 105, at 23-24 (discussing how the Committee has a lack of commitment to the CEDAW and its goals). 
procedure for violations of the CEDAW. ${ }^{123}$ The Protocol is not yet in force. ${ }^{124}$ Seventeen States are parties to the Protocol, ${ }^{125}$ and forty-nine States signed the Protocol. ${ }^{126}$ Afghanistan is not one of them. ${ }^{127}$

\section{The International Covenant on Economic, Social, and Cultural Rights}

The International Covenant on Economic, Social, and Cultural Rights (CESCR) has 143 States Parties ${ }^{128}$ and eight signatories. ${ }^{129}$ Afghanistan became a States Party to the CESCR on January 24, $1983 .{ }^{130}$ The CESCR promotes equality for men and women, ${ }^{131}$ the right to work, ${ }^{132}$ the right to an

123. See U.N. GAOR, 54th Sess., 28th plen. mtg., Agenda Item 109, at 281, U.N. Doc. A/RES/54/4 (1999), reprinted at 39 I.L.M. 281 (2000).

124. See Status of Ratifications of the Principal International Human Rights Treaties, supra note 107. The Optional Protocol is open for signature to any State that has signed, ratified, or acceded to the CEDAW. See U.N. GAOR, 54th Sess., 28th plen. mtg., Agenda Item 109, at 281. U.N. Doc. A/RES/54/4 (1999), reprinted in 39 I.L.M. 281 (2000).

125. The States Parties are: Austria, Bangladesh, Bolivia, Croatia, Denmark, Finland, France, Hungary, Iceland, Ireland, Italy, Mali, Namibia, New Zealand, Senegal, Slovakia, Thailand. See Status of Ratifications of the Principal International Human Rights Treaties, supra note 107.

126. The signatories are: Argentina, Azerbaijan, Belgium, Benin, Bosnia and Herzegovina, Bulgaria, Chile, Colombia, Costa Rica, Cuba, Cyprus, Czech Republic, Dominican Republic, Germany, Ghana, Greece, Guatemala, Guinea-Bisau, Indonesia, Kazakhstan, Lesotho, Liechtenstein, Lithuania, Luxembourg, Madagascar, Mexico, Mongolia, Netherlands, Nigeria, Norway, Panama, Paraguay, Peru, Philippines, Portugal, Romania, Sao Tome and Principe, Sierra Leone, Slovenia, Spain, Sweden, Tajikistan, Former Yugoslav Republic of Macedonia, Turkey, Ukraine, Uruguay, and Venezuela See id.

127. See id.

128. The States Parties to the CESCR are: Afghanistan, Albania, Algeria, Angola, Argentina, Armenia, Australia, Austria, Azerbaijan, Bangladesh, Barbados, Belarus, Belgium, Benin, Bolivia, Bosnia and Herzegovina, Brazil, Bulgaria, Burkina Faso, Burundi, Cambodia, Cameroon, Canada, Cape Verde, Central African Republic, Chad, Chile, Colombia, Congo, Costa Rica, Cote d'Ivoire, Croatia, Cyprus, Czech Republic, Democratic People's Republic of Korea, Democratic Republic of the Congo, Denmark, Dominica, Dominican Republic, Ecuador, Egypt, El Salvador, Equatorial Guinea, Estonia, Ethiopia, Finland, France, Gabon, Gambia, Georgia, Germany, Ghana, Greece, Grenada, Guatemala, Guinea, Guinea-Bissau, Guyana, Honduras, Hungary, Iceland, India, Islamic Republic of Iran, Iraq, Ireland, Israel, Italy, Jamaica, Japan, Jordan, Kuwait, Kyrgyzstan, Latvia, Lebanon, Lesotho, Libyan Arab Jamahiriya, Liechtenstein, Lithuania, Luxembourg. The Former Yugoslav Republic of Macedonia, Madagascar, Malawi, Mali, Malta, Mauritius, Mexico, Monaco, Mongolia, Morocco, Namibia, Nepal, Netherlands, New Zealand, Nicaragua, Niger, Nigeria, Norway, Panama, Paraguay, Peru, Philippines, Poland, Portugal, Republic of Korea, Republic of Moldova, Romania, Russian Federation, Rwanda, Saint Vincent and the Grenadines, San Marino, Senegal, Seychelles, Sierra Leone, Slovakia, Slovenia, Solomon Islands, Somalia, Spain, Sri Lanka, Sudan, Suriname, Sweden, Switzerland, Syrian Arab Republic, Tajikistan, Thailand, Togo, Trinidad and Tobago, Tunisia, Turkmenistan. Uganda, Ukraine, United Kingdom of Great Britain and Northern Ireland, United Republic of Tanzania, Uruguay, Uzbekistan, Venezuela, Viet Nam, Yemen, Yugoslavia, Zambia, and Zimbabwe. See id.

129. The signatories are Belize, China, Lao People's Democratic Republic, Liberia, Sao Tome and Principe, South Africa, Turkey, and the United States of America. See id.

130. See id.

131. Part II, Article 2 states, " 2 . The States Parties to the present Covenant undertake to guarantee that the rights enunciated in the present Covenant will be exercised without discrimination of any kind as to race, colour, sex, language, religion, political or other opinion, national or social origin, property, birth or other status." International Covenant on Economic, Social; and Cultural Rights, Sept. 28, 1966, 1966 U.S.T. 52 [hereinafter CESCR]. See also 
adequate standard of living, ${ }^{133}$ the right to a healthy life, ${ }^{134}$ the right to an education, ${ }^{135}$ and the right to partake in cultural life, ${ }^{136}$ among many other rights and freedoms. ${ }^{137}$

\section{The International Covenant on Civil and Political Rights}

The International Covenant on Civil and Political Rights (CCPR) has 148 States Parties ${ }^{138}$ and six signatories. ${ }^{139}$ Afghanistan became a States Party

International Covenant on Economic, Social, and Cultural Rights, reprinted in TWENTY-FIVE Human Rights DoCUMENTs 11 (1994). Part II, Article 3 states, "The States Parties to the present Covenant undertake to ensure the equal right of men and women to the enjoyment of all economic, social and cultural rights set forth in the present Covenant." CESCR, supra at 79.

132. Part III, Article 6 states in part, "I. The States Parties to the present Covenant recognize the right to work, which includes the right of everyone to the opportunity to gain his living by work which he freely chooses or accepts, and will take appropriate steps to safeguard this right." Id. at 80.

133. Part III, Article 11 states in part:

1. The States Parties to the present Covenant recognize the right of everyone to an adequate standard of living for himself and his family, including adequate food, clothing and housing, and to the continuous improvement of living conditions. The States Parties will take appropriate steps to ensure the realization of this right, recognizing to this effect the essential Id. at 84. importance of international cooperation based on free consent.

134. Part III, Article 12 states in part, "1. The States Parties to the present Covenant recognize the right of everyone to the enjoyment of the highest attainable standard of physical and mental health." Id. at 85.

135. Part III, Article 13 states in part,

1. The States Parties to the present Covenant recognize the right of everyone to education ....

2. The States Parties to the present Covenant recognize that, with a view to achieving the full realization of this right:

(a) Primary education shall be compulsory and available free to all;

(b) Secondary education in its different forms, including technical and vocational secondary education, shall be made generally available and accessible to al by every appropriate means, and in particular by the progressive introduction of free education;

(c) Higher education shall be made equally accessible to all, on the basis of capacity, by every appropriate means, and in particular by the progressive introduction of free education;

(d) Fundamental education shall be encouraged or intensified as far as possible for those persons who have not received or completed the whole period of their primary education;

(e) The development of a system of schools at all levels shall be actively pursued, an adequate fellowship system shall be established, and the

Id. at 85-87. material conditions of teaching staff shall be continuously improved.

136. Part III, Article 15 states in part, "1. The States Parties to the present Covenant recognize the right of everyone: (a) To take part in cultural life. ..." Id. at 88.

137. See generally id. Parts I-III, at 77-88.

138. The parties to the CCPR are: Afghanistan, Albania, Algeria, Angola, Argentina, Armenia, Australia, Austria, Azerbaijan, Bangladesh. Barbados, Belarus, Belgium, Belize, Benin, Bolivia, Bosnia and Herzegovina, Botswana, Brazil, Bulgaria, Burkina Faso, Burundi, Cambodia, Cameroon, Canada, Cape Verde, Central African Republic, Chad, Chile, Colombia, Congo, Costa Rica, Cote d'Ivoire, Croatia, Cyprus, Czech Republic, Democratic People's Republic of Korea, Democratic Republic of the Congo, Denmark, Dominica, Dominican Republic, Ecuador, Egypt, El Salvador, Equatorial Guinea, Estonia, Ethiopia, Finland, France, Gabon, Gambia, Georgia, Germany, Ghana, Greece, Grenada, Guatemala, Guinea, Guyana, Haiti, Honduras, Hungary, Iceland, India, Islamic Republic of Iran, Iraq, Ireland, Israel, Italy, 
to the CCPR on June $9,1995 .{ }^{140}$ The CCPR provides for equality between men and women, ${ }^{141}$ the right to liberty and security, ${ }^{142}$ right to privacy, ${ }_{1}^{143}$ right to freedom of thought, ${ }^{144}$ marriage rights, ${ }^{145}$ political rights, ${ }^{146}$ and prohibits

Jamaica, Japan, Jordan, Kuwait, Kyrgyzstan, Latvia, Lebanon, Lesotho, Libyan Arab Jamahiriya, Liechtenstein, Lithuania, Luxembourg, The Former Yugoslav Republic of Macedonia, Madagascar, Malawi, Mali, Malta, Mauritius, Mexico, Monaco, Mongolia, Morocco, Mozambique, Namibia, Nepal, Netherlands, New Zealand, Nicaragua, Niger, Nigeria, Norway, Panama, Paraguay, Peru, Philippines, Poland, Portugal, Republic of Korea, Republic of Moldova, Romania, Russian Federation, Rwanda, Saint Vincent and the Grenadines, San Marino, Senegal, Seychelles, Sierra Leone, Slovakia, Slovenia, Somalia, South Africa, Spain, Sri Lanka, Sudan, Suriname, Sweden, Switzerland, Syrian Arab Republic, Tajikistan, Thailand, Togo, Trinidad and Tobago, Tunisia, Turkmenistan, Uganda, Ukraine, United Kingdom of Great Britain and Northern Ireland, United Republic of Tanzania, Uruguay, United States of America, Uzbekistan, Venezuela, Viet Nam, Yemen, Yugoslavia, Zambia, and Zimbabwe. See Status of Ratifications of the Principal International Human Rights Treaties, supra note 107.

139. The signatories to the CCPR are China, Guinea-Bissau, Lao People's Democratic Republic, Liberia, Sao Tome and Principe, and Turkey. See id.

140. See id.

141. Part II, Article 2 states in part:

1. Each State Party to the present Covenant undertakes to respect and to ensure to all individuals within its territory and subject to its jurisdiction the rights recognized in the present Covenant, without distinction of any kind, such as race, colour, sex, language, religion, political or other opinion, national or social origin, property, birth or other status.

International Covenant on Civil and Political Rights, Oct. 5, 1977, 1966 U.S.T. 521, 95, 97-98 [hereinafter CCPR]. See also International Covenant on Civil and Political Rights, reprinted in TwENTY-FIVE Human Righrs DocumenTs 17 (1994). Part II, Article 3 states, "The States Parties to the present Covenant undertake to ensure the equal right of men and women to the enjoyment of all civil and political rights set forth in the present Covenant." Id. at 98. Part III, Article 26 states:

All persons are equal before the law and are entitled without any discrimination to the equal protection of the law. In this respect, the law shall prohibit any discrimination and guarantee to all persons equal and effective protection against discrimination on any ground such as race, colour, sex, language, religion, Id. at 113 .

political or other opinion, national or social origin, property, birth or other status.

142. Part III, Article 9 states in part, "1. Everyone has the right to liberty and security of person ...."Id. at 102-03.

143. Part III, Article 17 states in part, "1. No one shall be subjected to arbitrary or unlawful interference with his privacy, family, home or correspondence, nor to unlawful attacks on his honour and reputation." Id. at 108-09.

144. Part III, Article 18 states in part, "1. Everyone shall have the right to freedom of thought, conscience and religion ...." Id. at 109. Part III, Article 19 states in part, " 1 . Everyone shall have the right to hold opinions without interference. 2. Everyone shall have the right to freedom of expression;" Id. at 109-10.

145. Part III, Article 23 states:

1. The family is the natural and fundamental group unit of society and is entitled to protection by society and the State.

2. The right of men and women of marriageable age to marry and to found a family shall be recognized.

3. No marriage shall be entered into without the free and full consent of the intending spouses.

4. States Parties to the present Covenant shall take appropriate steps to ensure equality of rights and responsibilities of spouses as to marriage, during marriage and at its dissolution. In the case of dissolution, provision shall Id. at 111-12. be made for the necessary protection of any children.

146. Part III, Article 25 states:

Every citizen shall have the right and the opportunity, without any of the distinctions mentioned in article 2 and without unreasonable restrictions:

(a) To take part in the conduct of public affairs, directly or through freely 
torture, ${ }^{147}$ among other rights and freedoms. ${ }^{148}$ The CCPR also provides for a remedy for those whose rights are violated. ${ }^{149}$

\section{E. The Convention Against Torture and Other Cruel, Inhuman or Degrading Treatment or Punishment}

The Convention Against Torture and Other Cruel, Inhuman or Degrading Treatment or Punishment (CAT) has 123 States Parties ${ }^{150}$ and eleven signatories. ${ }^{151}$ Afghanistan became a States Party to the CAT on June 9, 1995. ${ }^{152}$ CAT defines torture as:

\section{[A]ny act by which severe pain or suffering, whether physical}
chosen representatives;
(b) To vote and to be elected at genuine periodic elections which shall be by universal and equal suffrage and shall be held by secret ballot, guaranteeing the free expression of the will of the electors;
(c) To have access, on general terms of equality, to public service in his country.

Id. at 112-13.

147. Part III, Article 7 states, "No one shall be subjected to torture or to cruel, inhuman or degrading treatment or punishment ...."Id. at 101.

148. See generally id., Parts I-III, at 96-113.

149. Part II, Article 2 states:

3. Each State Party to the present Covenant undertakes:

(a) To ensure that any person whose rights or freedoms as herein recognized are violated shall have an effective remedy, notwithstanding that the violation has been committed by persons acting in an official capacity;

(b) To ensure that any person claiming such a remedy shall have his right thereto determined by competent judicial, administrative or legislative authorities, or by any other competent authority provided for by the legal system of the State, and to develop the possibilities of judicial remedy;

(c) To ensure that the competent authorities shall enforce such remedies when granted.

Id. at 98 .

150. The parties to the CAT are: Afghanistan, Albania, Algeria, Antigua and Barbuda, Argentina, Armenia, Australia, Austria, Azerbaijan, Bahrain, Bangladesh, Belarus, Belgium, Belize, Benin, Bolivia, Bosnia and Herzegovina, Botswana, Brazil, Bulgaria, Burkina Faso, Burundi, Cambodia, Cameroon, Canada, Cape Verde, Chad, Chile, China, Colombia, Costa Rica, Cote d'Ivoire, Croatia, Cuba, Cyprus, Czech Republic, Democratic Republic of the Congo, Denmark, Ecuador, Egypt, El Salvador, Estonia, Ethiopia, Finland, France, Gabon, Georgia, Germany, Ghana, Greece, Guatemala, Guinea, Guyana, Honduras, Hungary, Iceland, Indonesia, Israel, Italy, Japan, Jordan. Kazakhstan, Kuwait, Kyrgyzstan, Latvia, Lebanon, Libyan Arab Jamahiriya, Liechtenstein, Lithuania, Luxembourg, The Former Yugoslav Republic of Macedonia, Malawi, Mali, Malta, Mauritius, Mexico, Monaco, Morocco, Mozambique, Namibia, Nepal, Netherlands, New Zealand, Niger, Norway, Panama, Paraguay, Peru, Philippines, Poland, Portugal, Qatar, Republic of Korea, Republic of Moldova, Romania, Russian Federation, Saudi Arabia, Senegal, Seychelles, Slovakia, Slovenia, Somalia, South Africa, Spain, Sri Lanka, Sweden, Switzerland, Tajikistan, Togo, Tunisia, Turkey, Turkmenistan, Uganda, Ukraine, United Kingdom of Great Britain and Northern Ireland, Uruguay, United States of America, Uzbekistan, Venezuela, Yemen, Yugoslavia, and Zambia. See Status of Ratifications of the Principal International Human Rights Treaties, supra note 107.

151. The signatories to the CAT are Comoros, Dominican Republic, Gambia, GuineaBissau, India, Ireland, Nicaragua, Nigeria, Sao Tome and Principe, Sierra Leone, and Sudan. See id. 
or mental, is intentionally inflicted on a person for such purposes as obtaining from him or a third person information or a confession, punishing him for an act he or a third person has committed or is suspected of having committed, or intimidating or coercing him or a third person, or for any reason based on discrimination of any kind, when such pain or suffering is inflicted by or at the instigation of or with the consent or acquiescence of a public official or other person acting in an official capacity. It does not include pain or suffering arising only from, inherent in or incidental to lawful sanctions. ${ }^{153}$

The CAT provides procedures for offenders ${ }^{154}$ and redress for victims. ${ }^{155}$ Political instability is no excuse for justifying torture. ${ }^{156}$

153. Convention Against Torture and Other Cruel, Inhuman, or Degrading Treatment or Punishment, Dec. 10, 1984, part I, art. I. para. 1, 1988 U.S.T. 202, 55 [hereinafter CAT]. See also Convention Against Torture and Other Cruel, Inhuman, or Degrading Treatment or Punishment, G.A. Res. 39/46, U.N. GAOR (1984), reprinted in TWENTY-FIVE HUMAN RIGHTS DOCUMENTS 71 (1994).

154. Part I, Article 6 states in part:

1. Upon being satisfied, after an examination of information available to it. that the circumstances so warrant, any State Party' in whose territory a person alleged to have committed any offence referred to in article 4 is present shall take him into custody or take other legal measures to ensure his presence. The custody and other legal measures shall be as provided in the law of that State but may be continued only for such time as is necessary to enable any criminal extradition processings to be instituted.

2. Such State shall immediately make a preliminary inquiry into the facts.

Id. at 58. Part I, Article 7 states in part:

1. The State Party in the territory under whose jurisdiction a person alleged to have committed an offence referred to in article 4 is found shall in the cases contemplated in article 5 , if it does not extradite him, submit the case to its

Id. at 59. competent authorities for the purpose of prosecution.

155. Part I, Article 13 states:

Each State Party shall ensure that any individual who alleges he has been subjected to torture in any territory under its jurisdiction has the right to complain to, and to have his case promptly and impartially examined by, its competent authorities. Steps shall be taken to ensure that the complainant and witnesses are protected against all ill-treatment or intimidation as a consequence of his complaint or any evidence given.

Id. at 62-63. Part I, Article 14 states in part:

1. Each State Party shall ensure in its legal system that the victim of an act of torture obtains redress and has an enforceable right to fair and adequate compensation, including the means for as full rehabilitation as possible. In the event of the death of the victim as a result of an act of torture, his dependents shall be entitled to compensation.

Id. at 63.

156. Part I, Article 2 states in part, " 2 . No exceptional circumstances whatsoever, whether a state of war or a threat of war, internal political instability or any other public emergency, may be invoked as a justification of torture." Id. at 56. 


\section{F. Who is Bound by These Human Rights Doctrines?}

The Taliban have a duty to respect international human rights law. ${ }^{157}$ There is a general presumption that existing treaties continue in force. ${ }^{158}$ United Nations officials reminded the Taliban that they are bound by the treaties to which Afghanistan is a party and are obligated to uphold the standards contained in these human rights instruments. ${ }^{159}$ The U.N. Special Rapporteur urged the Taliban to repeal any rules or edicts that contradict the provisions of the human rights documents to which Afghanistan is a party. ${ }^{160}$

Initially, the Taliban agreed to abide by the treaties to which Afghanistan is a party. ${ }^{161}$ After the Taliban's victory in Kabul in 1996, the Acting Deputy Foreign Minister of the Taliban reported, "all previous contracts and treaties would continue."162 While the Taliban Governor indicated that the Taliban would be willing to accept the human rights instruments, provisions contradicting Islamic law would not be enforced. ${ }^{163}$ The Attorney-General of the Taliban told the U.N. Special Rapporteur,

[I] f a promise, convention, treaty or other instrument, even if it was in the Charter of the United Nations, was contrary to Shariah, they would not fulfil [sic] it or act on it.... The core of our action and our policy is the law of God, as contained in the Koran. ${ }^{164}$

The Taliban told U.N. officials that "any discussion about human rights and international legal obligations was an attempt to interfere with religion, customs and tradition." 165 According to the U.N., this is not a justification for discriminatory practices. ${ }^{166}$ Even though various human rights instruments

157. "[A]ll Member States have an obligation to promote and protect human rights and fundamental freedoms and to fulfil [sic] the obligations they have freely undertaken under the various international instruments." Situation of Human Rights in Afghanistan, G.A. Res. 48/152, U.N. GAOR, U.N. Doc. A/RES/48/152 (1994). See David J. Scheffer, Ambassador at Large for War Crimes Issues, Address at the 50th anniversary of the Universal Declaration of Human Rights (Sep. 16, 1998), available in LEXIS, Department of State Dispatch file.

158. See TALMON, supra note 86, at 137.

159. See Interim Report on the Situation of Human Rights in Afghanistan (1996), supra note 53, 11 88, 89, 97; Final Report on the Situation of Human Rights in Afghanistan (1996), supra note 49, I 72; Situation of Human Rights in Afghanistan, U.N. GAOR, 55th Sess., Agenda Item 116 (c), 163, U.N. Doc. A/55/346 (2000) [hereinafter Situation of Human Rights in Afghanistan (2000)].

160. See Situation of Human Rights in Afghanistan (2000), supra note 160, 958.

161. See Interim Report on the Situation of Human Rights in Afghanistan (1996), supra note $53,158$.

162. Id.

163. See Final Report on the Situation of Human Rights in Afghanistan (1997), supra note $53,133$.

164. Id. 131.

165. Id. 115 .

166. The Taliban authorities need to understand that their obligations under international human rights instruments cannot be met, and violations cannot be justified, by invoking grounds based on subjective versions of religious or cultural prescriptions, many of which cannot be 
bind the Taliban, by creating rules that violate these documents, the Taliban gives little regard to protected rights and freedoms. ${ }^{167}$

The treaties to which Afghanistan is a party also bind the Rabbani government. ${ }^{168}$ Since the U.N. recognizes the Rabbani government, ${ }^{169}$ this government may validly sign, ratify, or accede to a multi-lateral inter-State treaty, ${ }^{170}$ such as the CEDAW. Since all countries do not recognize the Rabbani government as the valid government, by signing or acceding to a treaty, relations would not exist between Afghanistan and the non-recognizing parties. ${ }^{171}$

\section{ThE SITUATION FOR WOMEN PRIOR TO THE TALIBAN TAKING CONTROL}

The Taliban conquered the capital, Kabul, in 1996..$^{172}$ "Before the Taliban took over Kabul, 70 percent of the teachers were women, 40 percent of the doctors were women, over half the school students were females, and women were employed in all areas of the workforce." 173 Women worked in the medical field, ${ }^{174}$ as deans of universities, ${ }^{175}$ judges, ${ }^{176}$ officers in the army, foreign diplomats, and helicopter pilots. ${ }^{177}$ Some women were students and studied medicine and nursing. ${ }^{178}$

Women knew their rights and engaged in all aspects of life including the social, economic, and political arenas. ${ }^{179}$ "[S]pecial attention was given to respect for human rights, notably freedom of expression: no censorship was

supported by authoritative religious texts, traditional Afghan practices or the practice of other Muslim countries.

Situation of Human Rights in Afghanistan (2000), supra note 160, 159.

167. See Final Report on the Situation of Human Rights in Afghanistan (1997), supra note

53, I21; Report on the Situation of Human Rights (1999), supra note 55, 118.

168. See TALMON, supra note 86 , at 140-44.

169. See Afghanistan Human Rights Practices, 1999, supra note 86; Amnesty International Annual Report 2000, available at http://www.web.amnesty.org (last visited Sept. 2, 2000).

170. See TALMON, supra note 86, at 122.

171. See id. at 123 .

172. See Eus, supra note 1 , at xix.

173. Id. at 62.

174. For example, in one hospital ninety out of four hundred hospital workers were women. See Final Report on the Situation of Human Rights in Afghanistan (1996), supra note 49, ๆ 42.

175. Women acted as deans of Kabul University. See id. Women were also deans and professors at the University of Balkh. See Interim Report on the Situation of Human Rights in Afghanistan (1996), supra note 53, 134.

176. See Interim Report on the Situation of Human Rights in Afghanistan (1996), supra note 53, 934.

177. "[T] here were 283 high-ranking women officers in the army and 18 women diplomats in the foreign service; furthermore, there were 2 female helicopter pilots." Id. 138.

178. See Final Report on the Situation of Human Rights in Afghanistan (1996), supra note 49, $72-43$.

179. See Interim Report on the Situation of Human Rights in Afghanistan (1996), supra note 53,918 . 
imposed or permitted."180 The Lawyers Association of Afghanistan created "an Islamic law board, a contemporary law board and a human rights commission board." 181 Seminars and other educational programs for women promoted awareness about human development, health, and the community. ${ }^{182}$

\section{RULES IMPOSED BY THE TALIBAN AND VIOLATIONS OF HUMAN RIGHTS DOCTRINES}

Whether the Taliban, or some other group is in power, pursuant to the CCPR, "[T]he State must not only refrain from committing human rights violations ... it should also prevent the violation of human rights and provide remedies for alleged human rights violations." 183

A statement made by a Taliban official of the Attorney General's Office to journalists summarizes the Taliban's views of women: "The face of a woman is a source of corruption for men who are not related to them."184 In 1994, the U.N. Special Rapporteur documented twenty-one ordinances regarding Afghan women's behavior. ${ }^{185}$ "These ordinances specified, inter alia, that a woman's veil must cover her whole body, that perfumed women are regarded as adulteresses, that a woman must not leave her house without her husband's permission, and that a woman must not look at strangers." 186

\section{A. Right to Freedom of Movement}

Afghan women have the right to freedom of movement according to the UDHR, ${ }^{187}$ the CEDAW ${ }^{188}$ and the CESCR. ${ }^{189}$ The Taliban impose rules that affect women socially. ${ }^{190}$ Women are not allowed to go outdoors without a male relative as an escort. ${ }^{191}$ Even then, women must walk quietly and refrain I50.

180. Final Report on the Situation of Human Rights in Afghanistan (1996), supra note 49,

181. Interim Report on the Situation of Human Rights in Afghanistan (1996), supra note 53,117 . The human rights board stated they had published over twenty-two statements discussing human rights on the radio, television, newspapers, and magazines. See id. The Lawyers Association of Afghanistan also provided legal aid. See id.; Final Report on the Situation of Human Rights in Afghanistan (1996), supra note 49, 155.

182. See Interim Report on the Situation of Human Rights in Afghanistan (1996), supra note $53,137$.

183. Final Report on the Situation of Human Rights in Afghanistan (1995), supra note 41, 7 20. See supra notes $139-150$ and accompanying text discussing CCPR.

184. Women in Afghanistan: the Violations Continue, Amnesty International Report, at http://www.amnesty.org/ailib/aipub/1997/ASA/31100597 (last modified Nov. 5, 1997).

185. The committee of the High Court allegedly issued the ordinances. See Afghanistan Human Rights Practices, 1994, U.S. Dept. of State, Mar. 1995, available in LEXIS, Department of State Dispatch.

186. Id.

187. See supra note 102.

188. See supra note 116.

189. See supra note 135.

190. For a general list of rules see Final Report on the Situation of Human Rights in Afghanistan (1997), supra note 53, I app. I, app. II. See Eus, supra note 1, at 63.

191. See Final Report on the Situation of Human Rights in Afghanistan (1996), supra note 
from laughing or talking loudly in the streets. ${ }^{192}$ Women are not allowed to go to hotels, even for weddings. ${ }^{193}$

Women are also affected in their home life. Windows of a woman's house must be painted black. ${ }^{194}$ Women are not allowed to wash clothes in streams. ${ }^{195}$

Women are affected by the Taliban's rules when they use transportation. When a woman rides in a car, all windows except the front must be painted black. ${ }^{196}$ Women may not ride in buses with men. ${ }^{197}$ Taxi drivers may only pick up women who are escorted by a man. ${ }^{198}$ If caught not following this rule, the taxi driver, the woman, and her husband may suffer punishment. ${ }^{199}$

\section{B. Freedom of Thought, Expression, Peaceful Assembly, and Association}

The UDHR, ${ }^{200}$ the CEDAW, ${ }^{201}$ and the CCPR ${ }^{202}$ protect these rights. "One manifestation of the freedom of expression is the way a person dresses and looks."203 According to the beliefs of the Taliban stated in documents published on the official Taliban website, women must hide their physical attractiveness so that men are not sexually attracted to them. ${ }^{204}$ The Taliban force women to wear the burqa or the hejab, a body covering. ${ }^{205}$ The burqa

49, In 70, 73; Final Report on the Situation of Human Rights in Afghanistan (1997), supra note 53, app. I; EuSs, supra note 1, at 63; The Implementation of Human Rights with Regard to Women, U.N. ESCOR, 52nd Sess., Agenda Item 5, ๆ 46, U.N. Doc. E/CN.4/Sub.2/2000/18 (2000)[hereinafter The Implementation of Human Rights with Regard to Women].

192. See EuLIS, supra note 1 , at 63.

193. See Final Report on the Situation of Human Rights in Afghanistan (1997), supra note 53, 183 , app. I; The Implementation of Human Rights with Regard to Women, supra note 191, \46.

194. See Interim Report on the Situation of Human Rights in Afghanistan (1997), supra note $90, \$ 92$.

195. In a Taliban decree issued by the General Presidency of Amr Bil Maruf in December 1996, number 11 states, "To prevent washing cloth by young ladies along the water streams in the city. Violator ladies should be picked up with respectful Islamic manner, taken to their houses and their husbands severely punished." RASHID, supra note 3, at 218-19. See Nancy Hatch Dupree, Afghan Women Under the Taliban, in FUNDAMENTALISM REBORN? AFGHANISTAN AND THE TALIBAN 145, 156 (William Maley ed., 1998); Euls, supra note 1, at 63.

196. See Ghasemi, supra note 20 , at 450.

197. See Telesetsky, supra note 45 , at 296.

198. See EuUS, supra note 1, at 63; Dupree, supra note 195, at 156; Final Report on the Situation of Human Rights in Afghanistan (1997), supra note 53, I app. I; See The Implementation of Human Rights with Regard to Women, supra note 191, 146.

199. See EuUS, supra note 1, at 63; Dupree, supra note 195, at 156; Final Report on the Situation of Human Rights in Afghanistan (1997), supra note 53, I app. I.

200. See supra notes $98,102$.

201. See supra note 117.

202. See supra note $144,146$. II 61.

203. Final Report on the Situation of Human Rights in Afghanistan (1997), supra note 53,

204. See Why Women Should Stay in Their Houses, at http://www.afghanie.com/taliban/women 1.htm (last visited Sept. 5, 2000)(on file with the Indiana International and Comparative Law Review).

205. See Ghasemi, supra note 20, at 450 ; Dupree, supra note 195 , at 151 . Some women 
is a garment that covers all parts of the body excluding the eyes, which are covered by dark mesh. ${ }^{206}$ The burqa is related to various health problems. ${ }^{207}$ Some women cannot afford a burqa $a^{208}$ and therefore must share one with others. ${ }^{209}$ Sexual harassment increased in Kabul after women were forced to wear the burqa ${ }^{210}$ Women may not have clothes made by a tailor ${ }^{211}$ and cannot wear white socks. ${ }^{212}$ Punishment results from not following the strict dress code. $^{213}$

Freedom of expression is also shown through participation in public activities. Some Afghan women and groups have protested the Taliban's rules. ${ }^{214}$ When the Taliban demonstrated against foreign interference, ${ }^{215}$ Afghan women reacted by protesting with signs, which stated, "Taliban law is not Islamic law." 216 In 1996, over 150 women peacefully demonstrated to object the Taliban closing women's bathhouses. ${ }^{217}$ The Taliban responded by beating, jailing, and turning a fire hose on the women. ${ }^{218}$

find wearing the hejab improper because it does not conform to the Sharia. See also Interim Report on the Situation of Human Rights in Afghanistan (1996), supra note 53, 1 71; The Implementation of Human Rights with Regard to Women, supra note 191, 146.

206. See Ghasemi, supra note 20, at 450 . Most women in Kabul wear the burqa but try to be fashionable by wearing bright colors. See Dupree, supra note 195, at 160 .

207. "Wearing the burqa is related to several health problems, including poor vision and hearing, skin rashes, respiratory difficulties, headaches, asthma, alopecia (hair loss) and depression." EuIS, supra note 1, at 62.

208. One burqa is estimated to cost one month's salary or nine dollars. See Ghasemi, supra note 20, at 450. See also Final Report on the Situation of Human Rights in Afghanistan (1997), supra note 53, 184 (burqa costs one month's salary for a civil servant). But see EuLS, supra note 1 , at 62 (noting that the cost of one burqa is two months salary).

209. See Euss, supra note 1, at 62.

210. More women were approached with indecent proposals. See Situation of Human Rights in Afghanistan, U.N. ESCOR, 54th Sess., Agenda Item 10, I 5, U.N. Doc. E/CN.4/1998/71 (1998).

211. In a Taliban decree issued by the General Presidency of Amr Bil Maruf in December, 1996, number 14 states, "To prevent sewing ladies cloth and taking female body measures by tailor. If women or fashion magazines are seen in the shop the tailor should be imprisoned." RASHID, supra note 3, at 218-19. See also Dupree, supra note 195, at 156.

212. See EuLS, supra note 1 , at 62 .

213. Women have been beaten for wearing the wrong color shoes. See Dupree, supra note 195, at 152. The beatings are intended to do more psychological damage than physical harm. See id. Interim Report on the Situation of Human Rights in Afghanistan (1996), supra note 49, 171. See also Final Report on the Situation of Human Rights in Afghanistan (1997), supra note 53, 127 (discussing how 225 women were beaten for not wearing their veils). The Taliban leader, Mullha Mohammad Omar, authorized the religious police to carry out light punishments on the street. See Interim Report on the Situation of Human Rights in Afghanistan (1997), supra note 90, 132. The court system was for the worst violations. See id.

214. A group of women in Mazar-i-Sharif held a conference and demonstration in opposition to the Taliban. See Final Report on the Situation of Human Rights in Afghanistan (1997), supra note 53,176. The women wrote a declaration to the United Nations SecretaryGeneral requesting the U.N. to urge the Taliban into changing their views about women. See id. They also called for more action by the U.N. See id.

215. On October 17, 1996, the Taliban held a demonstration in Kabul. See Dupree, supra note 195 , at 161 .

216. Id. at 161 .

217. See Final Report on the Situation of Human Rights in Afghanistan (1997), supra note $53,741,62$; Dupree, supra note 195 , at 161

218. See Final Report on the Situation of Human Rights in Afghanistan (1997), supra note $53,162$. 
One woman took a stance against the Taliban. ${ }^{219}$ Najiba Sara Biabani created a radio show to inform Afghans about "land mines, narcotics, health, hygiene, women's rights, education, and domestic problems." ${ }^{220}$ The Taliban threatened her, and she eventually went into hiding. ${ }^{221}$

The Taliban infringes on women's freedom of association rights. ${ }^{222}$ Women are not allowed to engage in social activities ${ }^{223}$ and are denied civil and political rights by not being allowed to associate in large groups. ${ }^{224}$

\section{Freedom of Religion}

Women's rights to religious freedom are protected by the UDHR ${ }^{225}$ and the CCPR. ${ }^{226}$

Under the Taliban's rule, women's freedom of religion rights are nonexistent. ${ }^{227}$ The shrines are closed to women on Wednesday, which was previously the woman's day to worship. ${ }^{228}$ Women are not allowed in public during certain times of the year, such as the holy month of Ramaddan, unless they have a legal excuse. ${ }^{229}$

\section{Right to Health Services}

Afghan women have a right to health services according to the UDHR, ${ }^{230}$ the CEDAW, ${ }^{23 !}$ and the CESCR. ${ }^{232}$ Even so, health care statistics for Afghan women are among the lowest in the world. ${ }^{233}$ The Taliban's rules

219. See Euus, supra note 1 , at 183-84.

220. Id. The show is aired at various times so that women can listen while their husbands are at the mosque if men disapprove. See id. at 184. The show's audience encompasses threefourths of Afghanistan's population. See id. at 183.

221. Najiba was forced to leave Afghanistan after her husband was hanged and she was threatened. See id. at 184-86. In Pakistan, she gave a speech on Afghanistan Independence Day. See id. at 185. The Taliban threatened Najiba with death threats and phone calls. See id. After being shot at, she went into hiding. See id. at 185-86. She is now safe in an undisclosed European country. See id. at 186. 147.

222. See The Implementation of Human Rights with Regard to Women, supra note 191,

223. See id.

224. See id.

225. See supra note 97.

226. See supra note 144. 147.

227. See The Implementation of Human Rights with Regard to Women, supra note 191,

228. See id. ๆ 47.

$53,183$.

229. See Final Report on the Situation of Human Rights in Afghanistan (1997), supra note

230. See supra note 100.

231. See supra note 114 .

232. See supra notes 133-34.

233. Women's life expectancy rates are estimated at forty-four years of age. See Afghanistan Human Rights Practices, 1999, supra note 86; Interim Report on the Situation of Human Rights in Afghanistan (1999), supra note 58, 144. Doctors are sparse (less than 1 per 10,000 people). See id. Afghanistan is ranked lowest in the world according to the Gender Disparity Index. See Report on the Situation of Human Rights in Afghanistan: Report of Special Rapporteur, Kamal Hossain, U.N. ESCOR, 56 th Sess., Agenda Item 9, at 4, U.N. Doc. 
have not helped this situation. ${ }^{234}$ The Taliban closed women's bathhouses, or hamams, in $1996{ }^{235}$ For many women, bathhouses were the only source of running water. ${ }^{236}$

The Taliban also imposed rules pertaining to how women receive medical attention. ${ }^{237}$ In 1997, hospitals were closed to women. ${ }^{238}$ Women could only go to a clinic without running water. ${ }^{239}$ In 1997 , due to international disapproval, the Taliban withdrew this policy. ${ }^{240}$ Currently, men and women must remain segregated in hospitals. ${ }^{241}$ Few hospitals are set aside to treat women and those that do are ill-equipped. 242

Originally, women could only receive medical treatment from female doctors. ${ }^{243}$ This posed a problem since most women were forbidden from working. ${ }^{244}$ Since June 1998, women may see male doctors if accompanied by a male relative. ${ }^{245}$ However, this poses a medical danger when a woman needs medical treatment and a male relative is not available to accompany her. ${ }^{246}$

The Taliban's rules affect pregnant women and babies. ${ }^{247}$ Male doctors may not deliver babies. ${ }^{248}$ A single maternity hospital serves the entire country. ${ }^{249}$ This situation has also affected women and children's mental

E/CN.4/2000/33 (2000) [hereinafter Report on the Situation in Afghanistan (2000)]. Factors used in this formulation are "female life expectancy, educational attainment and income." Id. 234. See EuIS, supra note 1, at 96-98.

235. The Taliban said the bathhouses were unIslamic. See id. at 62; Ghasemi, supra note 20 , at 452. Doctors predict gynecological and uterine infections and scabies cases will rise. See Telesetsky, supra note 45, at 297; Final Report on the Situation of Human Rights in Afghanistan (1997), supra note 53, 185.

236. See EuLS, supra note 1, at 62 . It was reported that less than one family in eight had access to safe drinking water in the cities. See Final Report on the Situation of Human Rights in Afghanistan (1996), supra note 49, 133.

237. See infra note 273.

238. See Telesetsky, supra note 45, at 299.

239. See id.

240. See id.

241. See Afghanistan Human Rights Practices, 1999, supra note 86.

242. See EuUs, supra note 1, at 96 . In Kabul, women were treated in only one hospital, which was partly under construction. See Afghanistan Human Rights Practices, 1999, supra note 86. 53, app. II.

243. See Final Report on the Situation of Human Rights in Afghanistan (1997), supra note

244. See infra notes $264-93$ and accompanying text.

245. See Afghanistan Human Rights Practices, 1999, supra note 86.

246. See Ghasemi, supra note 20 , at $450-51$.

247. Afghanistan has the second highest rate of maternal death during delivery. See Eus, supra note 1, at 97. Reasons for maternal deaths include small pelvic size due to malnutrition, pregnancies close together in time, and infections. See id. Almost all babies are delivered at home without medical personnel. See id. Because of malnourished mothers, it is estimated that low birth weights account for one in five babies. See id. Low birth weight is related to blindness, deafness, mental retardation, and cerebral palsy. See id. The matemal death rate in 1990 was 1700 per 100,000 live births. See 1999 ABC-CLIO, Inc., Facts \& Figures, at LEXIS, Kaleidoscope. The projection for the years 2000 to 2010 of infant deaths is 141 per 1000 live births. Id.

248. See Ghasemi, supra note 20 , at 451.

249. See Afghanistan Human Rights Practices, 1999, supra note 86; Interim Report on the Situation of Human Rights in Afghanistan (1999), supra note 58, 54 . In 1996, only one maternity hospital was open in Kabul. See Final Report on the Situation of Human Rights in 
health. ${ }^{250}$ Many women suffer from mental illness ${ }^{251}$ or drug addiction. ${ }^{252}$ Children are also mentally affected. ${ }^{253}$

At the end of 1999, there were signs of improvement. ${ }^{254}$ Access to health care improved, and some of the restrictions were not in place at year end. ${ }^{255}$ In Kabul, all hospitals except the military hospital gave medical care to women. ${ }^{256}$ Despite these improvements, "Health services reach only 29 per cent [sic] of the total population, but only 17 per cent [sic] of the rural population."257

\section{E. Right to Employment}

The UDHR, ${ }^{258}$ the CEDAW, ${ }^{259}$ and the $\mathrm{CESCR}^{260}$ protect women's employment rights. These rights held true while Afghanistan was under Communist rule in the $1980 \mathrm{s.}^{261}$ Many women worked outside the home. ${ }^{262}$ In 1992, when the Communist government was overthrown, fewer women worked outside the home. ${ }^{263}$

When the Taliban came to power in 1994, women could not work in any areas other than education or health care. ${ }^{264}$ Initially, the Taliban stated the

Afghanistan (1997), supra note 53, 1 103. The equipment was over twenty years old and did not include an ultrasound device. See id. The hospital was funded solely through international aid. See id.

250. See EuIS, supra note 1, at 110-12.

251. A recent study of women's health in Kabul by Physicians for Human Rights showed that 81 percent of the Afghan women interviewed reported a decline in their mental health in the last year. Thirty-five percent had mental health problems so severe they significantly interfered with their daily activities. Ninety-seven percent of those interviewed were struggling with major depression.

Id. at 110 . For a story of an Afghan husband recounting the hardship of his wife's mental illness and lack of proper medical treatment, see id. at 109-10. See also The Implementation of Human Rights with Regard to Women, supra note 191, 26.

252. See The Implementation of Human Rights with Regard to Women, supra note 191, I125. In 1999, Afghanistan was the world's largest producer of opium. See The Situation in Afghanistan and Its Implications for International Peace and Security, supra note 57, I 63.

253. "In 1997 a UNICEF study of the psychological difficulties of the children of Kabul showed that three-quarters of three hundred children they interviewed had lost someone from their family between 1992 and 1996." EuJS, supra note 1, at 111. All the children had seen acts of war. See id. Ninety percent believed they would die from a rocket attack. See id. at 112. Children are unaware of health and hygiene facts because of their lack of education. See id. at 98. See also Situation of Human Rights in Afghanistan, U.N. ESCOR, 54th Sess., Agenda Item 10, I 8, U.N. Doc. E/CN.4/1998/71 (1998).

254. See Afghanistan Human Rights Practices, 1999, supra note 86.

255. See id.

256. See id.

58,944

257. Interim Report on the Situation of Human Rights in Afghanistan (1999), supra note

258. See supra note 99.

259. See supra note 113.

260. See supra note 132.

261. See U.S. DEP'T OF STATE, AfGHanistan Human Rights Practices, 1994 (Mar. 1995), available in LEXIS.

262. See id.

263. See id.

264. See Final Report on the Situation of Human Rights in Afghanistan (1995), supra note 
ban on employment was temporary. ${ }^{265}$ The Taliban reported that women could work after standards were in place for workplace gender segregation. ${ }^{266}$ Women did not receive their promised salaries to stay at home. ${ }^{267}$ Punishment, including beatings, resulted when women protested the ban on employment. ${ }^{268}$

In 1996 after the conquest of Kabul, the Taliban banned women from working, even in health care. ${ }^{269}$ There were many educated women in Kabul. ${ }^{270}$ These women told the U.N. Special Rapporteur Mr. Choong-Hyun Paik that they felt devalued and treated the same as illiterate persons. ${ }^{271}$ Due to the need to staff health care facilities, the Taliban gave permission for women to work in the health field ${ }^{272}$ subject to many rules. ${ }^{273}$ The Taliban also allowed women to work in a knitting factory. ${ }^{274}$ Due to an inability to

41, 7 36; , U.S. DEPT. OF STATE AFGHANISTAN HuMan RIGHTS PRACTICES, 1995 (Mar. 1996), available in LEXIS; U.S. DEPT. OF STATE, AFGHANISTAN HUMAN RIGHTS PRACTICES, 1994 (Mar. 1995), available in LEXIS.

265. See Interim Report on the Situation of Human Rights in Afghanistan (1996), supra note 53,971 .

266. See id.

267. See U.S. DeP'T of State, AfGhanistan Human Rights Practices, 1994 (Mar. 1997), available in LEXIS.

268. See U.S. DeP'T OF STATE, AFGHANISTAN HuMAN Rights PRACTICES, 1994 (Mar. 1997), available in LEXIS.

269. Up to 40,000 women were affected. See id.

270. See supra notes $299,331-34$ and accompanying text.

$53,72$.

271. See Final Report on the Situation of Human Rights in Afghanistan (1997), supra note

272. See U.S. DeP'T Of STATe, AfGhanistan Human Rights Practices, 1994 (Mar. 1997), available in LEXIS.

273. Rules of work for the State Hospitals and private clinics based on Islamic Sharia principles. Ministry of Health, on behalf of Amir ul Momineen Mullah Mohammed Omar. Kabul, November 1996.

1. Female patients should go to female physicians. In case a male physician is needed, the female patient should be accompanied by her close relative.

2. During examination, the female patients and male physicians both should be dressed with Islamic hijab (veil).

3. Male physicians should not touch or see the other parts of female patients except for the affected part.

4. Waiting room for female patients should be safely covered.

5. The person who regulates turn for female patients should be a female.

6. During the night duty, in what rooms which female patients are hospitalized, the male doctor without the call of the patient is not allowed to enter the room.

7. Sitting and speaking between male and female doctors are not allowed, if there be need for discussion, it should be done with hijab.

8. Female doctors should wear simple clothes, they are not allowed to wear stylish clothes or use cosmetics or make-up.

9. Female doctors and nurses are not allowed to enter the rooms where male patients are hospitalised

10. Hospital staff should pray in mosques on time.

11. The Religious Police are allowed to go for control at any time and nobody can prevent them. Anybody who violates the order will be punished as per Islamic regulations.

RASHID, supra note 3, at 218. See also Final Report on the Situation of Human Rights in Afghanistan (1997), supra note 53, app. II. 53,775 .

274. See Final Report on the Situation of Human Rights in Afghanistan (1997), supra note 
work or a lack of available jobs, many women resorted to begging and selling their possessions to provide for their families. ${ }^{275}$ Others resorted to prostitution. ${ }^{276}$ Widows are especially hit hard by the restrictions on employment. ${ }^{277}$ Because of years of civil war, some women are widowed and do not have any male relatives. ${ }^{278}$ These women face difficulties leaving their homes to buy food for their children. ${ }^{279}$ Since many widows are unable to work, children in the family must work to provide for the family. ${ }^{280}$ Some children dig up human remains to sell. ${ }^{281}$

In 1999, the Taliban began to allow women with no income to seek employment. ${ }^{282}$ However, many widows did not know of the change, and the number of jobs available was limited. ${ }^{283}$

The Taliban also placed restrictions on how widows received aid. ${ }^{284}$ Initially, widows could receive assistance from aid agencies only through male relatives. ${ }^{285}$ In 1999 , this reportedly changed, and women could independently claim international assistance. ${ }^{286}$

Some employment restrictions were lifted in $1999 .{ }^{287}$ A limited number of women were given the opportunity to work for international agencies or nongovernmental agencies. ${ }^{288}$ Women were also allowed to work as nurses

275. See Afghanistan Human Rights Practices, 1999, supra note 86; Telesetsky, supra note 45, at 297; Final Report on the Situation of Human Rights in Afghanistan (1997), supra note $53, \mathrm{II} 72,100$.

276. Many women pretend to be beggars and instead perform prostitution acts with shopkeepers. See M. Ilyas Khan, Beyond Good or Evil, Herald Magazine, at $\mathrm{http}: / / \mathrm{www}$. rawa.org/ilyas.htm (last visited Aug. 1999). The storeroom or attic of the shop is used. See id. The Revolutionary Association of Women of Afghanistan estimates that there are twenty-five to thirty brothels in Kabul. See id. The Taliban receive services at the brothels at no cost. See id.

277. In Kabul, it is estimated that 30,000 women are widowed. See Afghanistan Human Rights Practices, 1999, supra note 86. A 1997 survey by the International Commission on Civil and Political Rights (ICRC) documented 50,000 widows with an average of seven to nine children per widow. See Dupree, supra note 195 , at 155 . In Bamyan, widows head fifteen percent of all households. See Interim Report on the Situation of Human Rights in Afghanistan (1999), supra note 58, 120.

278. See ELLIS, supra note 1, at 62.

279. See Final Report on the Situation of Human Rights in Afghanistan (1996), supra note 49 , II $70,73$.

280. See Euls, supra note 1, at 62; Final Report on the Situation of Human Rights in Afghanistan (1997), supra note 53, 1100.

281. "Disturbances in the ground caused by rocket explosions has brought human remains closer to the surface of the ground, making it easier for little hands to get at the bones." EuJs, supra note 1, at 62. The bones are used to make "cooking oil, soap, chicken feed, and buttons." Id. See Final Report on the Situation of Human Rights in Afghanistan (1997), supra note 53, $\$ 100$.

282. See Afghanistan Human Rights Practices, 1999, supra note 86; Interim Report on the Situation of Human Rights in Afghanistan (1999), supra note 58, I 53.

283. See Afghanistan Human Rights Practices, 1999, supra note 86.

284. See id.; Interim Report on the Situation of Human Rights in Afghanistan (1997), supra note $90,195$.

285. See Afghanistan Human Rights Practices, 1999, supra note 86; Interim Report on the Situation of Human Rights in Afghanistan (1997), supra note 90. 195.

286. See Afghanistan Human Rights Practices, 1999, supra note 86.

287. See id.; Interim Report on the Situation of Human Rights in Afghanistan (1999), supra note 58, 153.

288. See Afghanistan Human Rights Practices, 1999, supra note 86. Women employees 
and doctors. ${ }^{289}$ Women could seek employment opportunities in agriculture and home-based crafts. ${ }^{290}$

In 2000, the Taliban took away some job opportunities available to women. Women were no longer allowed to work for the United Nations or nongovernmental agencies. ${ }^{291}$ In July, 2000, the Taliban prohibited women from working for foreign agencies outside of the health sector. ${ }^{292}$ In August, 2000 , the Taliban closed a bakery in Kabul, which employed many women and sold bread to the city's poorest women. ${ }^{293}$

\section{F. Right to Education}

Afghan women and girls have a right to education under the UDHR, ${ }^{294}$ the CEDAW, ${ }^{295}$ and the CESCR. ${ }^{296}$ Before the Taliban came to power, urban boys and girls engaged in this right through free education. ${ }^{297}$ Some conservative rural families chose to keep girls at home. ${ }^{298}$ Prior to the Taliban taking over Kabul, many female professors and educated persons who wanted to ensure education for their daughters left the city. ${ }^{299}$

After the Taliban came to power, rules forbade girls from attending school; however, the rules varied from region to region. ${ }^{300}$ In Kabul, for example, announcements on the radio and in the streets stated girls were not allowed to attend school. ${ }^{301}$ In most areas, girls could not attend school or vocational training projects. ${ }^{302}$ Some schools stayed open despite the

were not allowed to go to the actual agency but instead reported to the project site. See Interim Report on the Situation of Human Rights in Afghanistan (1999), supra note 58, 153.

289. See Interim Report on the Situation of Human Rights in Afghanistan (1999), supra note 58 , I 53.

290. "Female employment opportunities are limited to carpet weaving, tailoring, embroidery, soap making, candle making, poultry raising, honey production and bakery activities." The Implementation of Human Rights with Regard to Women, supra note 191, 142.

291. See The Implementation of Human Rights with Regard to Women, supra note 191, I 44; Situation of Human Rights in Afghanistan (2000), supra note 159, 148.

292. See Situation of Human Rights in Afghanistan (2000), supra note 159, I 56.

293. See id.

294. See supra note 101.

295. See supra note 115.

296. See supra note 135.

297. See EuLS, supra note 1, at 127.

298. See id.

299. See Final Report on the Situation of Human Rights in Afghanistan (1997), supra note $53,977$.

300. See Interim Report on the Situation of Human Rights in Afghanistan (1997), supra note 90, II 71-72; Afghanistan Human Rights Practices, 1999, supra note 86.

301. See EuIs, supra note 1, at 62.

302. See Final Report on the Situation of Human Rights in Afghanistan (1996), supra note 49, I 69. In September, 1995, girls' schools in Kandahar were closed. See id. Il 73. In September 1996, girls' schools in Kabul were closed. See Final Report on the Situation of Human Rights in Afghanistan (1997), supra note 53, 177. "It has been reported that 63 schools were closed in Kabul and that more than 103,000 girls, 148,000 boys and almost 8,000 female teachers were affected." $1 d$. There were no schools open for girls in Jalabad. See Situation of Human Rights in Afghanistan, U.N. ESCOR, 54th Sess., Agenda Item 10, I 1, U.N. Doc. E/CN.4/1998/71 (1998) [hereinafter Situation of Human Rights in Afghanistan (1998)]. 
restrictions. ${ }^{303}$

The Taliban assert that schools licensed by the Taliban are allowed.$^{304}$ In order to obtain a license, the school must not allow girls over eight years of age to attend and must teach only the Qur' an. ${ }^{305}$ The age restriction for girls stems from the Taliban's belief that girls and boys should not commingle in schools after age nine. ${ }^{306}$ A Taliban official acting as the Deputy Governor of Herat admitted that the Koran provides for education for everyone. ${ }^{307}$ The Taliban Acting Minister of Higher and Vocational Education "stated that it was an obligation in Islam for both boys and girls to go to school but that schools must be segregated to avoid corruption." ${ }^{308}$

Alternatives to public education for girls, such as radio programs ${ }^{309}$ and home schools, ${ }^{310}$ provide girls with a means of education. In some areas, home schools are the only available source of education for girls, ${ }^{311}$ and the Taliban even closed some of the home schools. ${ }^{312}$

The Taliban give many excuses for why girls are not being educated. The Taliban assert that girls may attend school after security improves. ${ }^{313}$ The

303. Some girls were able to attend elementary or home schools. See Afghanistan Human Rights Practices, 1999, supra note 87.

304. See id.; Ghasemi, supra note 20, at 453. The U.N. Special Rapporteur on Violence Against Women, visited one of the Taliban's schools. See The Implementation of Human Rights with Regard to Women, supra note 191, 140. The textbooks contained pictures of guns and torpedoes. See id.

305. See Afghanistan Human Rights Practices, 1999, supra note 86; Ghasemi, supra note 20 , at 453.

53, ๆ 80 .

306. See Final Repart on the Situation of Human Rights in Afghanistan (1997), supra note

307. See id. 74.

308. Id. II 73, 83.

309. A program called New Home, New Life was developed by the British Broadcasting Corporation. See Interim Report on the Situation of Human Rights in Afghanistan (1997), supra note 90, I 82. It discusses "cultural, social, economic, human rights, peace, health, conflict resolution, mine awareness and other issues of vital daily importance for the population of Afghanistan." Id.

310. See Interim Report on the Situation of Human Rights in Afghanistan (1996), supra note 53,ף 35; Afghanistan Human Rights Practices, 1999, supra note 86; Interim Report on the Situation of Human Rights in Afghanistan (1999), supra note 58, I 52.

311. See Interim Report on the Situation of Human Rights in Afghanistan (1996), supra note 53, I 27. The Taliban has "obstructed informal tutoring." Situation of Human Rights in Afghanistan (2000), supra note 159, 153. In Kabul, home school teachers must register with the religious police. See id. In rural areas, where the religious police are not prevalent, home schools are easier to conduct without intervention by the Taliban. See id. "Externally supported education programmes (especially in nural areas) provide education to an estimated 7 per cent [sic] of a total of 4.4 million children of primary school age." Implementation of Human Rights with Regard to Women, supra note 191, 134.

312. In 1998 in Kabul over 100 girls schools funded by nongovemmental organizations and home vocational programs were shutdown. See Afghanistan Human Rights Practices, 1999, supra note 86. The Taliban closed many private and home schools in 1998 stating that the schools were dispersing anti-Taliban propaganda. See Ghasemi, supra note 20, at 452-53.

313. See EuIS, supra note 1, at 128. The Taliban took over the city of Kandahar in 1994 and the schools are still not open. See id. One of the Taliban's excuses is that "their front-line soldiers would not be able to concentrate on killing people if they knew that women were walking the streets on their way to school." Id. The Taliban told the U.N. Special Rapporteur on Violence Against Women in 1999 that girls ages six through ten were allowed to receive primary education from mosque schools. See Afghanistan Human Rights Practices, 1999, supra note 86. Public schools however are only for boys. See id. Girls and boys are allowed to attend 
Taliban also claim there are insufficient funds for girls to attend school..$^{314}$ Some officials stated that the situation was not a high priority and a solution would be found later. ${ }^{315}$ The Taliban also said, "If we allowed it [education] in this city, there would be protests in other parts of the country." 316 Supposedly, some members of the Taliban in Afghanistan educate their daughters in Pakistani schools. ${ }^{317}$

Some reports show an easing of restrictions on education for girls. ${ }^{318}$ In 1999, the Taliban reported that girls ages five to ten could receive primary education through schools licensed by the Taliban. ${ }^{319}$ Other reports state only boys may attend the Taliban licensed schools. ${ }^{320}$

Other countries ${ }^{321}$ and organizations ${ }^{322}$ have offered to provide funds for integrated schools. ${ }^{323}$ The United Nations reports females, up to high school age, are allowed to attend private schools or schools funded through international organizations. ${ }^{324}$

Regardless of the form of education available, only a small portion of the female Afghan population is attending school. ${ }^{325}$ The United Nations reported at the end of 1998, "hardly any girls and only 24 per cent [sic] of boys attend school." ${ }^{326}$ Not surprisingly, Afghanistan's illiteracy rate of over seventy-five percent ranks as one of the highest globally. ${ }^{327}$ The female

schools funded by nongovernmental organizations or international donors. See Dupree, supra note 195, at 154; Final Report on the Situation of Human Rights in Afghanistan (1997), supra note 53, 177. Most officials note that areas controlled by the Taliban are peaceful and secure so the Taliban's excuses are not valid. See Final Report on the Situation of Human Rights in Afghanistan (1997), supra note 53. 1114.

$53,180$.

314. See Final Report on the Situation of Human Rights in Afghanistan (1997), supra note

315. See id.

316. Interim Report on the Situation of Human Rights in Afghanistan (1997), supra note $90,198$.

317. See id. 178.

318. See Interim Report on the Situation of Human Rights in Afghanistan (1999), supra note 58, 78, 51; The Implementation of Human Rights with Regard to Women, supra note 191, I 40; Situation of Human Rights in Afghanistan (2000), supra note 159, 53.

319. See Interim Report on the Situation of Human Rights in Afghanistan (1999), supra note $58,151$.

320. See The Implementation of Human Rights with Regard to Women, supra note 191, 132. Boys have also been affected through the restrictions on female employment. See Final Report on the Situation of Human Rights in Afghanistan (1996), supra note 49, $769,73$. Since the majority of teachers are women, boys' schools have been closed and reopened various times depending on whether the Taliban allow women to work in the educational field. See id. 73.

321. Norway offered to provide financial aid for schools in Kabul if boys and girls could both attend. See Interim Report on the Situation of Human Rights in Afghanistan (1997), supra note $90,180$.

322. The United Nations Children's Fund (UNICEF) and the United Nations Educational, Scientific and Cultural Organization (UNESCO) offered funding for schools if girls and boys could attend. See id. 18. The Taliban refused these offers. See id.

323. See id. 980.

324. See Situation of Human Rights in Afghanistan (2000), supra note 159, 153.

325. See Report on the Situation of Human Rights (1999), supra note 55, 117.

326. Id.

327. The literacy rate for females is the lowest of all countries in Asia. See Final Report on the Situation of Human Rights in Afghanistan (1997), supra note 53, 177. 
illiteracy rate is ninety-six percent. ${ }^{328}$

\section{Obstacles for Afghan Women Attaining Secondary Education}

Women are also discouraged from receiving a higher education. ${ }^{329}$ The Taliban closed Kabul University and then reopened it with only males in attendance..$^{330}$ Additionally, the Taliban closed a medical teaching facility in Kandahar. ${ }^{331}$

The Taliban eased restrictions in 2000 . The Taliban allowed forty medical students to continue their medical education at Kabul University. ${ }^{332}$ A nursing school in Herat reopened and the Taliban made plans to start a nursing school in Kandahar. ${ }^{333}$

\section{Violations of Human Rights Doctrines}

The Special Rapporteur emphasized that the Taliban's lack of official commitment to educating girl children is a violation of international law and Afghanistan's commitments under the International Covenant on Economic, Social and Cultural Rights, the Convention on the Elimination of All Forms of Discrimination Against Women and the Convention on the Rights of the Child. ${ }^{334}$

\section{G. Rights Against Torture}

Torture is prohibited under the UDHR, ${ }^{335}$ the CCPR, ${ }^{336}$ and the CAT. ${ }^{337}$ The Taliban strictly enforce laws, and physical punishments result from breaking the rules. ${ }^{338}$ Every Friday in Kabul, the Taliban force crowds into the soccer stadium to witness beatings, whippings, limbs being cut off, or

328. See Afghanistan Human Rights Practices, 1999, supra note 86.

329. See infra notes 331-32 and accompanying text.

330. Ten thousand students, four thousand of which were females, attended the University before it was shut down in 1996. See Eus, supra note 1, at 128; Interim Report on the Situation of Human Rights in Afghanistan (1996), supra note 53,971.

331. The school was shut down because the staff was all male. See Final Report on the Situation of Human Rights in Afghanistan (1996), supra note 49, 175 . The World Health Organization's nursing school was shut down. See U.S. DEP'TOFSTATE, AFGHANISTAN HUMAN RIGHTS PRACTICES, 1996 (Mar. 1997), at LEXIS, Department of State Dispatch. The Taliban indicated that at some point in the future women "would be allowed to study medicine, education and moral and other social subjects." Interim Report on the Situation of Human Rights in Afghanistan (1997), supra note 90, 173. 129.

332. See The Implementation of Human Rights with Regard to Women, supra note 191,

333. See id.

334. Id. 941.

335. See supra note 93.

336. See supra note 147.

337. See supra note 153.

338. See EuUS, supra note 1, at 63-64. See also supra notes 199, 213, 218. 
executions. ${ }^{339}$ For example, the Taliban punish those who commit adultery by stoning them to death, and homosexuals are killed by a collapsing wall. ${ }^{340}$ The Taliban issue arrests and lashings for disobeying the clothing rules. ${ }^{341}$ One woman who wore nail polish had her thumb cut off. ${ }^{342}$ The Taliban's actions are "described as amounting to cruel and degrading treatment and punishment." 343

\section{H. Right to Partake in Government}

Afghans have the right to partake in their government under the UDHR, ${ }^{344}$ the CEDAW, ${ }^{345}$ and the CCPR. ${ }^{346}$ After the Communist government fell, the Constitution was discarded. ${ }^{347}$ The Taliban told the U.N. Special Rapporteur, Mr. Kamal Hossain, that the Taliban is drafting a new constitution. ${ }^{348}$ Allegedly, religious scholars are preparing a new constitution $^{349}$ in contrast to the prior procedures of engaging in public comment and approval. ${ }^{350}$ The U.N. suggested, "If, indeed, a constitution was being prepared, such a constitution must be accepted by representatives of all segments of the Afghan population, such representatives to be elected according to procedures which were in conformity with the Covenant [CCPR]." 351 Furthermore, the U.N. noted that "Afghans have continued to be prevented from choosing their government in a peaceful and democratic manner." 352 Through these acts, the Taliban is in violation of Article 21 of the UDHR and Article 26 of the CCPR. ${ }^{353}$

339. See EuUS, supra note 1, at 63 .

340. See id.

341. Women wearing veils too long were beaten with chains. See Final Report on the Situation in Afghanistan (1997), supra note 53, III 40-41; ELLS, supra note 1, at 64 .

342. See EluIS, supra note 1 , at 64.

343. Final Report on the Situation in Afghanistan (1997), supra note 53,140. See Interim Report on the Situation of Human Rights in Afghanistan (1999), supra note 58, I 48.

344. See supra note 98.

345. See supra note 117 .

346. See supra note 146.

347. See EuLIS, supra note 1 , at xviii.

348. See Report on the Situation of Human Rights in Afghanistan (2000), supra note 159, 1 9; Interim Report on the Situation of Human Rights in Afghanistan (1999), supra note 58, I 37. The Special Rapporteur noted,

The fact that the Taliban themselves recognize the need for a constitution to be drawn up underlines the need to develop an inclusive process which would enable all segments of the Afghan population to participate in working out an acceptable constitutional framework and procedures for its acceptance and approval by the Afghan people.

Report on the Situation of Human Rights in Afghanistan (2000), supra note 159, II 10.

349. See Interim Report on the Situation of Human Rights in Afghanistan (1999), supra note $58,937$.

350. The prior process consisted of the Loya Jirga (or national assembly) made up of elected and nominated officials who approved the Constitution. See id.

351. Id. 139. 192.

352. Final Report on the Situation of Human Rights in Afghanistan (1997), supra note 53, stated:

353. The Special Rapporteur of the Commission on Human Rights, Mr. Kamal Hossain, 


\section{Cultural Relativism}

The Taliban claim to follow the principles of the Islamic religion. ${ }^{354}$ For a complete analysis of the situation, the Taliban's acts must be assessed in relation to the Islamic culture. "Cultural relativism is the "claim that rights and rules about morality . . . are encoded in and thus depend on cultural context." "355

"Ninety-nine percent of Afghanistan is Muslim and follow the teachings of Islam." 356 Muslims believe that individuals have a precise role in society. ${ }^{357}$ "In Islam, religion governs politics, economics, and law." 358 The Qur'an, ${ }^{359}$ the sacred scripture of Islam, outlines the criteria and beliefs for Muslims. ${ }^{360}$ Some basic beliefs are common to all Muslims. ${ }^{361}$

The most fundamental denial of human rights which needed to be addressed was that of the right of the people of Afghanistan effectively to participate in the governance of their country through freely chosen representatives. This is the right recognized in article 21 of the Universal Declaration of Human Rights. . . and elaborated in article 26 of the International Covenant on Civil and Political Rights, to which Afghanistan is a party.

Report on the Situation of Human Rights in Afghanistan (2000), supra note 159, I 3.

354. See Desai, supra note 80, at 819; Final Report on the Situation of Human Rights in Afghanistan (1997), supra note 53, 133 . A Taliban representative stated in a interview,

The Taliban are running a system of government, based on being subordinate to the rule of Sharee'ah, where the Taliban rulers and the public in subjection to a system of Sharee'ah, are accountable in front of a court of Law. Whether the crime is committed by a ruler or his subjects, both are subjected to the Islamic Penal Code and both are deserving of it's [sic] punishment and it is for this reason that the lives and wealth of people today, in this region will be seen to be safe and secure.

Nazeer Laghari and Mufti Jameel Khan, Interview with the Ameerul M'umineen, at http://www/afghan-ie.com/taliban/intviewl htm (last visited Sept. 5, 2000)(on file with the Indiana International and Comparative Law Review).

355. Desai, supra note 80, at 809 (quoting INTERNATIONAL HUMAN RIGHTS IN CONTEXT 192 (Henry J. Steiner \& Philip Alsten eds., 1996)). According to this theory, "notions of right (and wrong) and moral rules necessarily differ throughout the world because the culture in which they inhere themselves differ." Id.

356. Telesetsky, supra note 44 , at 295 . Afghanistan was involved in an Islamic revivalism during the 1970s and 1980s. See Oliver Roy, Has Islamism a Future in Afghanistan?, in FUNDAMENTALISM REBORN? AFGHANISTAN AND THE TALIBAN 199-200 (William Maley ed., 1998).

357. 357See Urfan Khaliq, Beyond the Veil?: An Analysis of the Provisions of the Women's Convention in the Law as Stipulated in Shari'ah, 6 BUFF. J. INT'L L. 1 (1995). By satisfying these roles, society as a whole is benefitted. See id.

358. Kathryn J. Webber, The Economic Future of Afghan Women: The Interaction Between Islamic Law and Muslim Culture, 18 U. PA. J. INT'L ECON. L. 1049, 1058 (1997). n.4.

359. The two common spellings are Koran or Qur'an. See Ghasemi, supra note 20, at 445

360. See Leila P. Sayeh and Adriaen M. Morse, Jr., Islam and the Treatment of Women: An Incomplete Understanding of Gradualism, 30 TEX. INT'LL.J. 31 1, 315 (1999). The Qur' an is made up of 114 chapters with 6,666 verses. See Khaliq, supra note 357, at 8.

The verses of the Qur-an, as a whole, differentiate between certain types of conduct, classifying behavior into the following categories: Fard (a compulsory duty, which is punishable if it is omitted); Haram (an unlawful or forbidden action, which is punishable); Mukruh (a disliked and disapproved action but one which carries no penalty); Jaiz (a permitted action, but one which is legally indifferent); and Maidub (an action which is rewarded, but whose omission is not 
Islamic jurisprudence is a mix of the primary sources of law, the Qur'an and the Sunnah, ${ }^{362}$ and the secondary sources of ijtihad, ${ }^{363}$ ijma, ${ }^{364}$ and $\mathrm{Al}$ Qiyas. ${ }^{365}$ The law that encompasses Islamic jurisprudence is the Shari' $a^{366}$ however this is not a formal legal code. ${ }^{367}$ The principles of the Shari'a affect all aspects of life. ${ }^{368}$

"Custom is a valid, recognized source of Islamic law."369 Due to local and cultural influences, the Shari'a was modified. ${ }^{370}$ Because of local customs, various regions of Afghanistan have different interpretations of the Qur'an. ${ }^{371}$ In reality, cultural norms limit the right to Islamic recognized rights. ${ }^{372}$

\section{A. Women's Role in the Islamic Culture}

The Shari' a provides a hierarchy ${ }^{373}$ for gender and classes ${ }^{374}$ with men having superior rights. ${ }^{375}$ The Qur'an states that women need guardians ${ }^{376}$ so they do not act sexually irresponsibly. ${ }^{377}$ The women's primary role in the

Id. at 8-9.

punishable).

361. See Khaliq, supra note 357 , at 7.

362. The example portrayed by the Prophet is the Sunnah. See Sayeh and Morse, supra note 360 , at 316 n.27. The Sunnah describes model behavior. See Khaliq, supra note 357, at 9. If the Sunnah contradicts the Qur'an, the law of the Qur' an is superior, as the Qur'an is the word of God. See id. The Sunnah and the Hadith, the recorded sayings of the Prophet, were completed after the Prophet's death. See id. at 10. To ensure authenticity, all author's works were compiled, and those principles which were repeated in others works where compiled to make up the Sunnah and the Hadith. See id.

363. "Ijtihad is the general term for legal reasoning or interpretation and the entailed use of reason and analogy to interpret the sacred sources of Islamic law." Sayeh and Morse, supra note 360 , at 316 n.28.

364. Ijma is the agreement of principles by the Ullamah, learned ones, or scholars on the Qur' an and the Sunnah. See Khalig, supra note 357, at 11 n.45.

365. "Al-Qiyas is a legal principle, introduced in order to derive a logical conclusion from a certain law on a certain issue that has to do with the welfare of Muslims." Id. at 11-12. The Qur'an, the Sunnah, or ljma must provide the foundation for the Al-Qiyas. See id. at 12. Many scholars are not supportive of using this principle. See id.

366. See Ghasemi, supra note 20, at 453. Sharia or Shari' ah means "path to follow." See Khaliq, supra note 357, at 7 (quoting Abdullah A. An-Na'im, Islamic Ambivalence to Political Violence, 31 GERMAN Y.B. INT'L L. 307, 315 (1988)).

367. See Desai, supra note 80 , at 821 .

368. See Khaliq, supra note 357 , at 7.

369. Webber, supra note 358 , at 1068.

370. See Khaliq, supra note 357 , at 7.

371. See Final Report on the Situation of Human Rights in Afghanistan (1995), supra note $41,121$.

372. For the social norms of Israel, Egypt, and the West bank, see Webber, supra note 358, at 1067-79.

373. The hierarchy is based on "religion, civil status, age and gender." Khaliq, supra note 357, at 13.

374. Mature male Muslims have the most rights. See id. at 13. Free, mature female Muslims have the second highest rights. See id. Non-Muslim female minors are accorded the fewest rights. See id.

375. This principle originated in Chapter 4, verse 34 of the Qur'an. See id. at 13-14.

376. Verse 4:34 states this. See id. at 14.

377. Women are thus often portrayed as willing and encouraging partners in leading men 'off the path' which they are supposed to follow, by having sexual 
Islamic society is child bearer. ${ }^{378}$

Under the Qu'ran, women have some enumerated rights. ${ }^{379}$ Women may engage in business contracts, independently own property, and partake in public life. ${ }^{380}$ Although under some interpretations women cannot request a divorce, women have the right to raise their children after their divorce. ${ }^{381}$ Men are responsible for the economic needs of the children. ${ }^{382}$

The Qu'ran states some rules that affect men and women differently, such as inheritance laws, dower, and marriage. ${ }^{383}$ Some of these rules are in women's favor. ${ }^{384}$ Other rules, such as the obedience doctrine, under which a woman has a duty to be obedient to her husband, can negatively affect women's rights. ${ }^{385}$ For example, men may use these rules to keep women from working outside the home. ${ }^{386}$

\section{B. The Taliban's Actions and Islam}

During the life of the Prophet Muhammad, women worked and participated actively in the culture ${ }^{387}$ and voiced opinions freely. ${ }^{388}$ The Hadith, ${ }^{389}$ the record of the Prophet Muhammad's life, promotes respect for

intercourse with them outside wedlock, leading to illegitimate children and immorality in society, which in turn leads to social unrest and a challenge to the Id. Islamic way of life.

378. See id. at 13. The idea is based on producing children to increase the population and the number of Muslims. See id. Women's motivation for conceding to this role is a reward in the after life for fulfilling their duty. See id. at 13 n.54.

379. See Telesetsky, supra note 45 , at 301.

380. See id.

381. See id.

382. The father must provide for a son until he reaches the age of eighteen and a daughter until she is married. See id.

383. Men are allowed to engage in polygamy with up to four wives at once. See Khaliq, supra note 357 , at 15 . Women can be married to only one man at a time. See id. Men can divorce at will while women must satisfy criteria. See id. Under inheritance law, men generally inherit more than women. See Webber, supra note 358, at 1061.

384. For dower the man must give the women money or property upon marriage. See id. at $\mathbf{1 0 6 2}$. It is seen as a symbol of respect. See id. Women in valid contractual marriages are entitled to maintenance. See id. at 1063-64. Maintenance is "food, clothing, lodging, and medical care." Id. at 1064 . The minimum requirement of maintenance is for three menstrual periods and is seldom paid after the minimum requirement. See Khaliq, supra note 357, at 15.

385. See Webber, supra note 358, at 1065-66. There are restrictions on the enforcement of maintenance that negatively affect women. See id. at 1063. Law requires that women obey their husbands and ask permission to leave the house. See id. at 1065.

386. "Using the obedience doctrine to prevent a woman from working generally is acceptable in the Muslim world." Id. at 1066. Men may stop providing maintenance. See id.

387. Prophet Muhammad's first wife worked in business, and his second wife was a political and religious leader. See Ghasemi, supra note 20, at 457.

388. See Telesetsky, supra note 45, at 302. See also Sayeh and Morse, supra note 360 , at 321-24 (discussing how men are required to respect women as the Prophet did.)

389. See Sayeh and Morse, supra note 360 , at 316 n.27. The Hadith is made up of the "recorded sayings of the Prophet." Khaliq, supra note 357, at 9. The Hadith states, "The best of you is he who is best to his wife,"; "Paradise is under the feet of the mother;"; and "All people are equal, as the teeth of a comb. There is no claim of merit of an Arab over an nonArab, or of a white over a black person or of a male over a female." Ghasemi, supra note 20, at 455 (quoting MUHAMMADE ABDUL-RAUF, THE ISLAMIC VIEW OF WOMEN AND THE FAMILY 
females.

"Prior to the success of the Taliban, individual households were free to enforce their own versions of moral codes without interference from the Ministry of Prevention of Vice and Promotion of Virtue."390 Now, Taliban leaders enforce the law as they see fit and prohibit individual interpretation. ${ }^{391}$

One Islamic scholar told a U.N. Special Rapporteur that the Taliban's interpretation of the Qur' an is incorrect. ${ }^{392}$ According to that scholar, "A strict reading of the Koran interprets women's rights and responsibilities as equal to men's responsibilities, but not identical. The Taliban uses this 'equal but different' philosophy to require women to stay at home and tend to domestic duties and childcare." 393 Therefore, a strict reading of the Qur'an may not support the ban on women working. ${ }^{394}$ Under the Qur'an, persons have a right to work for a living. ${ }^{395}$ The Taliban violate this strict interpretation of Islamic law through restrictions on female employment. ${ }^{396}$

The Taliban requirement that women wear the burqa also appears to violate Islamic law. ${ }^{397}$ The Qur'an does not specify that women must cover their face and hair, although the Islamic tradition is to wear a veil. ${ }^{398}$ Other Islamic countries, such as Iran, do not require women to wear a burqa. ${ }^{399}$

Another infringement of Islamic law by the Taliban is the closing of women's bathhouses. ${ }^{400}$ Many women no longer have access to water for bathing ${ }^{401}$ despite the usual Islamic emphasis on cleanliness and good personal hygiene. ${ }^{402}$

Furthermore, the Taliban violate Islamic law by restricting female educational opportunities. ${ }^{403}$ The Qur' an promotes education ${ }^{404}$ and does not set educational limitations on females. ${ }^{405}$ The Prophet Muhammad promoted education for all women." 406 "Some Islamic scholars believe that the Taliban

$21,25(1977))$.

390. Telesetsky, supra note 45 , at 302 .

391. See id.

$53,129$.

392. See Final Report on the Situation of Human Rights in Afghanistan (1997), supra note

393. Telesetsky, supra note 45 , at 301.

394. See Ghasemi, supra note 20 , at 456.

395. See id. at 457.

396. See id. For the rules regarding Afghan women and employment see notes 259-94 and accompanying text.

397. See Ghasemi, supra note 20 , at 457-58. For a discussion of the burqa, see notes 205 13 and accompanying text.

398. See id.

399. In Iran, women wear veils that cover only their head and neck. See id.

400. See Telesetsky, supra note 45 , at 296-97.

401. See supra note 235 and accompanying text.

402. See Telesetsky, supra note 45 , at 296-97.

403. See supra notes 294-334 and accompanying text.

404. The Qur'an states, "Proclaim! (or Read!) in the name of thy Lord and Cherisher, who created ... man, out of a leech-like clot: proclaim! [sic] and thy Lord is most bountiful. He who taught (the use of) the pen, taught man that which he knew not." Ghasemi, supra note 20, at 458 (quoting Qur'an at 96:1-5).

405. See id.; Telesetsky, supra note 45, at 301.

406. See Sayeh and Morse, supra note 360, at 325. 
have distorted the Koranic teachings to ignore basic premises such as mandatory education for both males and females." ${ }^{107}$ Other Muslim countries, such as Jordan, Kuwait, and Bahrain, improved their primary education system for females. ${ }^{408}$ Girls attend school regularly in some Muslim countries. $^{409}$

\section{Islamic Practices in Other Countries}

Other Islamic countries are shocked by the Taliban's strict interpretation of the Qu'ran. ${ }^{410}$ Iran is critical of the Taliban's policies, ${ }^{411}$ and Pakistan attempts to differentiate their policies from those of the Taliban. ${ }^{412}$

\section{Methods For CHANGE}

\section{A. Gradualism}

Under the theory of gradualism, the situation for women improves as changes are made within the Islamic culture. ${ }^{413}$ Gradualism encourages a liberal interpretation of the Islamic religion. ${ }^{414}$ Gradualism is described as "a method of interpretation that proceeds by degrees, over time, advancing slowly but regularly."415 Islam experienced gradualism in women's rights through changes in the areas of education ${ }^{416}$ and marital consent. ${ }^{417}$ Based on these historical experiences, Islam may provide a means for change under the theory of gradualism. ${ }^{418}$

A division exists among scholars regarding whether interpretations of the Qur' an may progressively change as society changes over time. ${ }^{419}$ Some

407. Telesetsky, supra note 45 , at 300 .

408. See Ghasemi, supra note 20 , at 458 .

409. See id.

410. See id. at 459 .

411. Iran reportedly financially supported anti-Taliban forces. See Ghasemi, supra note 20 , at 459. Iranian officials charge that the Taliban's policies give the Islamic religion a bad name. See id. Islamic groups in Pakistan made this same assertion. See Telesetsky, supra note 45, at 300-01.

412. In 1998 when the Pakistan government switched from a British common law system to the Qur'an, the Prime Minister emphasized that women's and minorities' rights would not be violated. See Ghasemi, supra note 20 , at 459 .

413. See Sayeh and Morse, supra note 360, at 331-32.

414. See id.

415. Id. at 318. See also Webber, supra note 358, at 1080-82.

416. Before the period in which the Prophet lived, known as Jahiliyyah, men dominated. See Sayeh and Morse, supra note 360, at 321-25. The Prophet used gradualism in education to equate women's status to that of men. See id.

417. During Jahiliyyah, the father decided if the daughter would be married based on gifts the potential husband offered to the father. See id. at 325. The Prophet allowed women the option of accepting or rejecting a marriage proposal. See id. Some Islamic cultures permit a wali, or male guardian, to accept or reject marriage proposals. See id. at 326. 204.

418. See Sayeh and Morse, supra note 360, at 330-31. But see Roy, supra note 356, at

419. See Khaliq, supra note 357 , at 6. 
scholars believe the Shari'a allows varying interpretations of existing precedent in certain situations. ${ }^{420}$ These situations include: "(1) necessity or public interest, (2) change in the facts which originally gave rise to the law, and (3) change in the custom or usage on which a particular law was based."421 If one of the above situations arises, existing law changes as long as it does not conflict with the Qur'an. ${ }^{422}$ The new law is then part of the Shari'a. ${ }^{423}$ Over time, judges closed the door of ijtihad, ${ }^{424}$ which limits flexibility in interpretation. $^{425}$ Pakistan revived the ijtihad, however, and may influence the Taliban into doing the same. ${ }^{426}$

\section{B. Organizations Help to Promote Awareness and Change}

Initially, the Taliban declared edicts regulating the behavior of female staff members of nongovernmental organizations. ${ }^{427}$ The Taliban also victimized women volunteers. ${ }^{428}$ No human rights organizations currently operate in Afghanistan. ${ }^{429}$

Other organizations work from outside the country or conduct underground activities. The Revolutionary Association of Women of Afghanistan (RAWA) ${ }^{430}$ promotes the rights of women in Afghanistan and Afghan refugees in Pakistan. ${ }^{431}$ RAWA's activities include holding demonstrations and press conferences, educating women through literacy and political courses, ${ }^{432}$ and managing a hospital, a school, and employment

420. See Sayeh and Morse, supra note 360 , at 317.

421. Id.

422. See id.

423. See id.

424. Closing the door of ijtihad is a process in which leaders of the tenth century limited interpretation to accepted schools. See id. at 318. Political reasons were the basis of this decision. See Khaliq, supra note 357, at 10-11. See also Webber, supra note 358, at 1081 .

425. See Khaliq, supra note 357, at 11 . See also Webber, supra note 358, at 1081.

426. See Webber, supra note 358, at 1083.

427. These regulations stated that Shari'a prevented women from working. See Interim Report on the Situation of Human Rights in Afghanistan (1997), supra note 90, 195, app. II.

428. Five CARE International women workers were forced out of their car. See Dupree, supra note 195, at 157. The woman had written authorization to perform their work. See id. The guards condemned the volunteers over a loudspeaker by saying they were prostitutes. See $i d$. Then, the guards whipped them with a metal and leather whip. See id. However, the Deputy Director of the religious police stated that the guards' acts were not authorized and apologized for the events. See id; Interim Report on the Situation of Human Rights in Afghanistan (1997), supra note $90,194$.

429. See Human Rights Watch 2000 Report, Asia Overview, at http://www.hrw.org/wr2k/Asia.htm (last visited Sept. 3, 2000).

430. RAWA was created in 1977 . See EuIS, supra note 1, at 216. For general information about RAWA see Desai, supra note 80, at 840-41; Revolutionary Association of Women in Afghanistan, at http://p2.rawa.org/rawa/index.html (last visited Mar. 27, 2001).

431. See Eus, supra note 1, at 216.

432. See id. at 216-18. Sajida, a RAWA activist, stated,

We want to at least raise their [women's] awareness of their own rights, because most Afghan women don't know about this. They think women should be the slaves of men. Our political courses are about women's rights, about the criminal activities of the Taliban, to disclose the real nature of the Taliban, so they know that what the Taliban is doing is not part of the Koran. 
projects. ${ }^{433}$ RAWA celebrates International Women's Day. ${ }^{434}$ RAWA must conduct activities underground in Afghanistan but may do so in public in Pakistan. ${ }^{43}$ RAWA conducts these activities despite threats to the participants' safety. ${ }^{436}$

Other groups that promote Afghan women's rights are the Feminist Majority Foundation ${ }^{437}$ and the Cooperation Center for Afghanistan. ${ }^{438}$ The European Union also addressed the situation in Afghanistan by encouraging the Taliban to end discrimination against women. ${ }^{439}$ The International Committee of the Red Cross also plays a crucial role in providing medical supplies and services. ${ }^{40}$

The Afghan Women's Network works with the United Nations to include women's thoughts in a solution for peace, to guarantee basic rights and to increase more female involvement in the United Nations and nongovernmental programs. ${ }^{441}$

Id. at 218.

433. See id. at 217.

434. On March 8, 1927, women gathered in Bukhara, tore off their burgas, and burned them in a bomb fire. See EuIs, supra note 1, at 221. Women who unveiled were raped, murdered, and shamed by their families. See id. Those that survived were blamed for causing an earthquake that happened later that year. See id. at 222. March 8 of every year is now a day of celebration to promote equality. See id. at 221. RAWA plans events for this occasion. See id. at 218.

435. See Euss, supra note 1, at 218.

436. Sajida describes how the Taliban threatened to hurt those involved in a planned demonstration in Pakistan to denounce the Taliban. See id. RAWA postponed the event. See id. In 1998, the Taliban told women that they would cut off their legs for partaking in the events for this day. See id. at 222. Deborah Ellis, a joumalist, attended one such event and received a note saying,

We have found that you are in contact with a group of prostitutes called RAWA.

These whores fight Islam .... You better save your life and leave this city and

let RAWA call girls continue to sell their bodies[,] but they will be stoned to death by our brothers and you will be informed about it soon.

Id. at 226. However, women in Afghanistan were allowed to celebrate International Women's Day on March 8, 2000. See The Implementation of Human Rights with Regard to Women, supra note 191, I 19. Over 700 women partook in a formal celebration. See id. A Taliban leader spoke at the gathering, which represented the first time a Taliban official addressed Afghan women in a public setting. See id.

437. The Feminist Majority Foundation is involved with activism campaigns to help end the apartheid of Afghan women. See Stop Gender Apartheid in Afghanistan, at http://www/feminist.org/afghan/facts.html (last visited Mar. 28, 2001). The campaigns include the Adopt an Afghan Girl's School campaign, the Afghan Women's Craft campaign, and the Afghan Women's Scholarship program. See id. The Feminist Majority Foundation works with other organizations, such as Amnesty International USA, Human Rights Watch, the International Women's Human Rights Law Clinic, the National Organization of Women, the National Political Congress of Black Women, the Women's Alliance for Peace and Human Rights in Afghanistan, and the World Council of Muslim Women Foundation, in the campaign to Stop Gender Apartheid in Afghanistan. See id.

438. See Press Release, Council of Ministers, 2239th Council Meeting (Jan. 24, 2000), available at LEXIS, RAPID File.

439. See id.

440. In 1993, the International Committee of the Red Cross (ICRC) was stationed in Kabul and Mazar-I-Sharif. See Final Report on the Situation of Human Rights in Afghanistan (1994), supra note 36, I 43.

441. See Interim Report on the Situation of Human Rights in Afghanistan (1996), supra note $53,121$. 


\section{United Nations}

The United Nations promotes equal rights for men and women. ${ }^{442}$ Afghanistan became a member of the U.N. on November 19, 1946. ${ }^{443}$ The U.N. is attempting to bring about change in Afghanistan. For example, the U.N. set up a special mission to Afghanistan in October, $1993 .{ }^{444}$ However, the resignation of two heads of the mission ${ }^{445}$ and the failure to facilitate negotiations between the Taliban and the Rabbani government ${ }^{446}$ hampered this mission.

The U.N. also gives aid, health supplies, food, water, and other staples, such as blankets and kerosene stoves, to the Afghan people and refugees. ${ }^{447}$ The United Nations Children's Fund (UNICEF) distributes door-to-door information on health and education issues and the CEDAW. ${ }^{448}$ Some U.N.

442. "We the peoples of the United Nations determined ... to reaffirm faith in fundamental human rights, in the dignity and worth of the human person, in the equal rights of men and women and of nations large and small ...."U.N. Charter preamble.

443. See List of Member States, at http://www.un.org/Overview/unmember.html (last visited Mar. 27, 2001). See AFG. ConST., reprinted in Felix Ermacora, Afghanistan, in CONSTITUTIONS OF THE COUNTRIES OF THE WORLD 6 (Albert P. Blaustein \& Gisbert H. Flanz eds., 1992).

444. See William Maley, The UN and Afghanistan: "Failure of a Mission", in FUNDAMENTALISM REBORN? AFGHANISTAN AND THE TALIBAN 182, 187 (William Maley ed., 1998).

445. Mahmoud Mestiri resigned four months prior to the Taliban's conquest of Kabul. See id. at 182. His predecessor, Dr. Norbert Holl, resigned in October 1997. See id. at 182-83.

446. See id. at 192. The Taliban claims that they no longer trust Burhanuddin Rabbani. Nazeer Laghari and Mufti Jameel Khan, Interview with the Ameerul M'umineen, at http://www/afghan-ie.com/taliban/intview1.htm (last visited Sept. 5, 2000)(on file with the Indiana International and Comparative Law Review). A Taliban representative said, "[T]hey [Burhanuddin and Hikmatyar] have always betrayed us, betrayed the nation, violated the agreements and unjustly spilled the blood of the Muslims, and now, we have no trust in them and neither is the Afghan nation willing to trust them." Id. It has been argued that the U.N. failed in its mission for Afghanistan. See Maley, supra note 444, at 198.

Missions can fail in at least six different ways. First, relevant internal issues can be overlooked. Second, relevant internal parties can be overlooked. Third, the contribution to destabilisation of external parties or issues can be over looked. Fourth, parties can lose confidence in the good faith of the mediator. Fifth, negotiations can be conducted too publicly, in such a way that the glare of publicity limits the flexibility of parties, and encourages them instead to posture for the benefit of their supporters. Sixth, the parties may simply not be interested in reaching an agreement at a given moment: the conflict may not be ripe for settlement. All these reasons for failure have played their role at one time or another in the Afghan case.

Id. at 197. To the contrary, sixty-three non-governmental organizations signed a letter to the secretary-general of the U.N. praising the U.N. for its efforts to help women in Afghanistan and setting forth several suggestions for continued assistance. See Protecting Afghan Women's Rights, NEW STRAITS TIMES (MALAYSIA), May 5, 1997, at 15, available at LEXIS, News, Asia \& Pacific Rim File. The recommendations included educating warring groups in Afghanistan about human rights, appointing women to participate in negotiation meetings with the Taliban, and arranging visits to Taliban controlled areas. See id.

447. See Final Report on the Situation of Human Rights in Afghanistan (1994), supra note 36 , ก $39-41$. II 30.

448. See The Implementation of Human Rights with Regard to Women, supra note 191, 
groups suspended aid and assistance in regions which discriminated against women. ${ }^{449}$

\section{The Taliban and the U.N.}

The Taliban play a role in the lives of female U.N. workers. During the U.N. special missions to Afghanistan, the Taliban prohibited U.N. female assistants from meeting Taliban officials. ${ }^{450}$ Many U.N. workers face violence and risk their own lives. ${ }^{451}$ The Taliban allegedly killed some U.N. workers. ${ }^{452}$

In August, 2000, the Taliban issued a statute which restricted the U.N.'s activities. ${ }^{43}$ The statute requires that the Taliban serve as the middlemen between the U.N. and the people. ${ }^{454}$ Understandably, this statute may hinder the U.N.'s ability to give assistance to the Afghan people. ${ }^{455}$

\section{The U.N.'s Recommendations}

\section{The Special Rapporteur, ${ }^{456}$ Mr. Kamal Hossain reported,}

[P]ervasive human rights problems are both a cause and consequence of the governance crisis. The character of the existing authorities, who rule without the consent and participation of the Afghan people, is the root cause of human rights violations .... The focus thus needs to shift from incremental changes to a framework change. ${ }^{457}$

449. UNICEF suspended its programs in Kandahar and Herat until discrimination stops. See Final Report on the Situation of Human Rights in Afghanistan (1996), supra note 49, 176. 450. See id. I 72; Final Report on the Situation of Human Rights in Afghanistan (1997), supra note 53 , 186.

451. In 1994, fighting was heavy in Kabul. See Final Report on the Situation of Human Rights in Afghanistan (1994), supra note 36, I 20. A 24-hour cease-fire was called so that U.N. staff and diplomats could leave the city. See id.

452. An unknown gunmen killed seven workers of the Organization for Mine Clearing and Rehabilitation (OMAR), a U.N. nongovernmental organization. See Seven Workers of UNAffiliated NGO killed in Afghanistan, NNI at http://www.rawa.org/7killed.htm (Aug. 7, 2000). The Taliban blamed the incident on another group, the Northem Alliance. See id; Final Report on the Situation of Human Rights in Afghanistan (1997), supra note 53, I 74; Situation of Human Rights in Afghanistan (1998) supra note 302, 12 . In 1998, a U.N. Special Mission to Afghanistan official was killed. See Report on the Situation of Human Rights in Afghanistan (1999), supra note 55, I 4.

453. See Situation of Human Rights in Afghanistan (2000), supra note 159, I 57.

454. See id.

455. See id.

456. The goals of the United Nations Special Mission to Afghanistan (UNSMA) were:

(a) to support the Special Envoy in promoting peace through contact with the two contending sides [the Taliban and the United Front] as well as through the wider Afghan political and civil community; (b) to monitor and report political and military developments in Afghanistan; and (c) to coordinate activities with the Office of the United Nations Coordinator for Afghanistan as well as the indigenous and international humanitarian assistance community.

Situation of Human Rights in Afghanistan (2000), supra note 159, I 61 .

457. The Special Rapporteur also said,

The circumstances which encourage this view include changes in the neighboring 
This framework change must involve the Afghan citizens and refugees. ${ }^{458}$ The U.N. Secretary General added:

The objective would be to rebuild Afghanistan and to restore the country to all of its people. This would only be possible through a negotiated peace and a process of transition aimed at the establishment of a broad-based, multi-ethnic and truly representative government.

Only such a government could be expected to repeal the edicts which result in systematic violations of human rights and to create the conditions under which basic human rights could be guaranteed to the women, men and children of Afghanistan, rights that they are entitled to by virtue of the fact that Afghanistan is a party to the main international human rights instruments. ${ }^{459}$

The Special Rapporteur also reported that helping the human rights situation requires ending the arms flow. ${ }^{460}$ In a recent report, the U.N. specifically urged the Taliban to lift restrictions on women. ${ }^{461}$

countries, the recent discussions among them, the meetings between the Taliban and their neighbours, the release of several hundred opposition prisoners by the Taliban, and the resolve expressed within the United Nations for positive action. Id. 160.

All these, taken together, present an opening which should not be missed.

458. See id. 155.

459. Id. If 62-63. Afghanistan is a party to the CCPR, CESCR, and CAT. See id. Afghanistan signed the CEDAW. See id.

460. "Stopping the arms flow must assume greater priority in the international community's endeavours to promote human rights in Afghanistan." Report on the Situation of Human Rights in Afghanistan, supra note 233, 156.

461. The U.N.

[u]rges all the Afghan parties, and in particular the Taliban, to bring to an end without delay all violations of human rights of women and girls and to take urgent measures to ensure:

a. The repeal of all legislative and other measures which discriminate against women and girls and those which impede the realization of all their human rights;

b. The effective participation of women in civil, cultural, economic, political and social life throughout the country;

c. Respect for the equal right of women to work, and their reintegration in employment;

d. The equal right of women and girls to education without discrimination, the reopening of schools and the admission of women and girls to all levels of education;

e. Respect for the right of women to security of person and that those responsible for physical attacks on women be brought to justice;

f. Respect for the freedom of movement of women;

g. Respect for effective and equal access by women and girls to the facilities necessary to protect their right to the highest attainable standard of physical and mental health;

Situation of Human Rights in Afghanistan, U.N. ESCOR, 19, U.N. Doc. E/CN.4/RES/2000/18 (2000). 


\section{REFUGEES}

Some Afghans felt the situation in Afghanistan was so bad that they had to leave the country. ${ }^{462}$ A large number of Afghans fled the country in the 1980s during the Soviet fighting. ${ }^{463}$ Afghan refugees account for the largest refugee group with 1.2 million in Peshawar, Pakistan. ${ }^{464}$ In Afghanistan, over one million Afghan refugees are internally displaced. ${ }^{465}$

The Convention Relating to the Status of Refugees has a specific definition for who is considered a refugee. ${ }^{466}$ Gender, however, is not included as a protected group in the definition ${ }^{467}$ and courts have not consistently construed who is a "particular social group." 468

For those who do fit the definition of refugee, some find life in the refugee camps is no different from life in Afghanistan. ${ }^{409}$ Many women live a strict lifestyle, including being forced to stay indoors. ${ }^{470}$ Many young girls are forced to stay inside with their mothers. ${ }^{471}$ A representative for Physicians for Human Rights reported that there were no showers, food, education, or work in some of the refugee camps. ${ }^{472}$

462. See EuLS, supra note 1, at 78-94 for testimonials of Afghan refugees.

463. See id. at 41.

464. See id. at 73. See also U.S. Dep't Of State, Afghanistan Human Rights PRACTICES, 1994 (Mar. 1995), available at LEXIS (states statistics for refugees in 1994); U.S. DEP'T OF STATE, AFGHANISTAN HUMAN RIGHTS PRACTICES, 1995 (Mar. 1996), available at LEXIS (states statistics for refugees in 1995); U.S. DEP'T OF STATE, AFGHANISTAN HUMAN RIGHTS PRACTICES, 1996 (Mar. 1997), available at LEXIS (states statistics for refugees in 1996); Afghanistan Human Rights Practices, 1999, supra note 86.

465. See ELUIS, supra note 1 , at 73.

466. Chapter I, Article 1 states:

A. For the purposes of the present Convention, the term "refugee" shall apply to any person who:... 2. owing to well-founded fear of being persecuted for reasons of race, religion, nationality, membership of a particular social group or political opinion, is outside the country of his nationality and is unable or, owing to such fear, is unwilling to avail himself of the protection of that country; or who, not having a nationality and being outside the country of his former habitual residence [as a result of such events], is unable or, owing to such fear, is unwilling to return to it.

Convention Relating to the Status of Refugees, reprinted in TWENTY-FIVE HUMAN RIGHTS DOCUMENTS, 57 (1994). See also Protocol to Convention on Status of Refugees, Oct. 4, 1967, art. I, para. 2, 19 U.S.T. 6223, reprinted in 6 I.L.M. 78 (discussing how the Protocol applies to all States Parties to the original Convention Relating to the Status of Refugees).

467. See Convention Relating to the Status of Refugees, supra note 466, at 57.

468. Peter C. Godfrey, Defining the Social Group in Asylum Proceedings: The Expansion of the Social Group to Include a Broader Class of Refugees, 3 J.L. \& POL'Y 257, 258, 270-74 (1994) (analyzing the extension of "particular social group" to include gender). See also Anjana Bahl, Home is Where the Brute Lives: Asylum Law and Gender-Based Claims of Persecution, 4 CARDOZO WOMEN'S L.J. 33 (1997) (discussing how gender based refugee claims fit within the definition of "particular social group" if violence against women is seen as a violation of human rights and not disregarded as a private issue).

469. See Euss, supra note 1 , at 76.

470. See id. at 74-75.

471. See id. at 75.

472. See id. at 76. He also reported that some women did not have a place to go to the restroom. See id. at 77 . They would have to refrain from going all day and after dark go to the edge of the camp so they could go to the bathroom on the hill. See id. 
Some women stay in the refugee camps with the children while the husbands fight the war in Afghanistan. ${ }^{473}$ Some women are separated from their extended families and live amongst strangers. ${ }^{474}$ Members of the Mujahideen groups, who led the camps and gave out the rations, force women to have sex in order to receive food for their children. ${ }^{475}$

Refugee camps are also a difficult adjustment for children. ${ }^{476}$ Many children are not enrolled in the camp schools. ${ }^{477}$ Safety for children is also a concern in the camps. ${ }^{478}$

\section{A. Afghan Refugees in Pakistan}

The refugees have taken an economic toll on Pakistan. ${ }^{479}$ Aid to the refugees in Pakistan has slowed or stopped. ${ }^{480}$ The Pakistani government stopped short of forcing the refugees out of their country. ${ }^{481}$ The government shut down four Afghan universities in Peshawar and a year later reopened them. ${ }^{482}$ Trying to facilitate the return of refugees to Afghanistan, the government stated in March of 1999 that all Afghans should anticipate being restricted to the confines of the camps. ${ }^{483}$

\section{B. Afghan Refugees in Iran}

Iran is also a host country for many Afghan refugees. ${ }^{484}$ In the beginning, the Iranian government welcomed the refugees because of a need for workers in the booming economy. ${ }^{485}$ Living conditions were reportedly better than in Pakistan. ${ }^{486}$ Many refugees lived in the city instead of in camps. ${ }^{487}$ Many jobs were available, and education was free. ${ }^{488}$ Many women

473. See id. at 74.

474. See id.

475. See id.

476. See id. at 74-75.

477. The children outnumber the available openings in the schools. See id. at 75 . The schools are free but some families have had to require the children to stay home and beg or work to support the family. See id.

478. Children have been kidnapped, have disappeared, and some have had body parts stolen. See id. One young girl, Sheela, vanished for a week. See id. When she returned home, one of her kidneys had been removed. See id. She died three days later. See id.

479. Refugees affected the labor market by working for lower wages. See id. at 88 . Rent in Peshawar increased because of the demands of aid workers, reporters, and U.N. officials for housing. See id.

480. "A staff member of the International Committee for the Red Cross considers Afghanistan and the refugees to be their largest under-funded program." Id.

481. See id.

482. See id. at 88-89.

483. See id. at 89.

484. See id. at 93.

485. See id.

486. See id.

487. See id. at 94.

488. See id. at 93. 
worked or attended school for the first time. ${ }^{489}$

In the 1990s, the economy slowed. ${ }^{490}$ Beginning in 1995, more refugees were housed in camps. ${ }^{491}$ Refugees were restricted from certain areas of the cities, known as "refugee-free zones." ${ }^{492}$ Anti-Afghan sentiments grew. ${ }^{493}$ The government introduced incentive packages for Afghans to return to Afghanistan. ${ }^{494}$

In 1998, the situation worsened after an Iranian journalist and seven Iranian diplomats were killed in Afghanistan. ${ }^{495}$ Iranians lashed out, and thirty Afghans were killed in a random act of violence. ${ }^{496}$ In November of 1998 , thousands of refugees were ordered to return to Afghanistan within three weeks. ${ }^{497}$

The head of the U.N. refugee agency is currently touring to hasten the return of Afghan refugees. ${ }^{498}$ Many Afghans are reluctant to return home because of the poor economic situation in the country and the strict rules for women. ${ }^{499}$

According to the Convention Relating to the Status of Refugees, Iran, as a party to this Convention, may not return Afghan refugees if a threat to their life or freedom exists. ${ }^{500}$ However, seventy thousand Afghan refugees were forcibly returned to Afghanistan between January and the end of September in $1999 .^{501}$

\section{Returning Home}

The Geneva Accords signed in 1988 provide a safeguard for Afghan refugees to return to Afghanistan voluntarily. ${ }^{502}$ Many refugees returned home

489. See id.

490. See id.

491. See id. at 94.

492. Id.

493. See id.

494. These packages were meant to help them through the first few months in Afghanistan. See id. at 93.

495. See id. at 94.

496. See id.

497. See id.

498. See Associated Press, Head of U.N. Refugee Seeks to Hasten Return of Afghans (Sept. 15, 2000), available at http://www.cnn.com/2000/ASIANOW/central/09/14/ pakistan. refugees.ap/index.html.

499. See id.; see also Euus, supra note 1, at 93-94. See also Iran: Are Returning Afghan Refugees Properly Protected? at http://web.amnesty.org/ai.nsf/index/MDE130282000?OPEN DOCUMENT\&of=COUNTRIES/IRAN (Sept. 26, 2000).

500. Chapter V, Article 33 states, "No Contracting State shall expel or retum ("refouler") a refugee in any manner whatsoever to the frontiers of territories where his life or freedom would be threatened on account of his race, religion, nationality, membership of a particular social group or political opinion." Convention Relating to the Status of Refugees, reprinted in TWENTY-FIVE HUMAN RIGHTS DOCUMENTS 64 (1994).

501. See The Situation in Afghanistan and Its Implications For International Peace and Security, supra note 57, In 53-54.

502. The U.N. Special Rapporteur, Mr. Kamal Hossain, noted:

Non-interference in the intermal affairs of Afghanistan and non-intervention were to be internationally guaranteed and the United Nations was entrusted with a 
between 1990 and 1995 after the Soviet reign ended. ${ }^{503}$

In 1997, the Taliban issued an amnesty decree for refugees to return to Afghanistan. ${ }^{504}$ "It provides guarantees for the safe and dignified return of refugees, respect for their basic human rights and exemption from prosecution for non-personal criminal offences committed before leaving the country, as well as for draft evasion and desertion."

\section{CONCLUSION}

No woman should be forced to leave her birth country so that she may enjoy activities, such as taking a stroll outside, without government interference. The Taliban's rules impact every aspect of a woman's life. The Taliban's rules violate human rights doctrines, to which Afghanistan is a party, and also violate the Islamic religion. The ideal solution to remedy these human rights violations is the implementation of a new governing structure which would allow popular input and would adhere to the governing human rights doctrines. Since this proposal appears out of reach while the Taliban remain in power, the best solution for now may be to attempt to influence the Taliban in their interpretation of the Qur' an and use of gradualism to promote women's rights.

Shannon A. Middleton *

monitoring role in relation to the interrelated set of obligations created by the Accords. It was expected that the human rights of the Afghan people would thus be safeguarded. This legitimate expectation remains unfulfilled to date. Report on the Situation of Human Rights (1999), supra note 55, I 19.

503. See EuUs, supra note 1, at 73. Eighty-two thousand refugees voluntarily returned to Afghanistan in the first nine months of 1999. See The Situation in Afghanistan and Its Implications For International Peace and Security, supra note 57, 153.

504. See Interim Report on the Situation of Human Rights in Afghanistan (1997), supra note 90 , I 70, app. I.

505. Id. 970.

* J.D. Candidate, 2002, Indiana University School of Law-Indianapolis; B.S., 1998, Management, Purdue University. Thank you to all my family members for their love and support. To my mother, thank you for being such a wonderful role model and source of encouragement. To my husband, Jason, thank you for your enduring faith and patience. To my dear friend, Katherine, thank you for your inspiration in the human rights area. 